\section{Pacific Northwest}

National Laboratory

Operated by Battelle for the

U.S. Department of Energy

\title{
Evaluation of Methods to Increase Light Under Ferry Terminals
}

\author{
Sue Blanton \\ Ron Thom \\ Amy Borde \\ Heida Diefenderfer \\ John Southard
}

Battelle Marine Sciences Laboratory

Sequim, Washington

January 2002

\author{
Prepared for \\ Washington State Department of Transportation \\ Research Office Olympia, Washington \\ under a Related Services Agreement \\ with the U.S. Department of Energy \\ under Contract DE-AC06-76RL01830
}




\section{DISCLAIMER}

This report was prepared as an account of work sponsored by an agency of the United States Government. Neither the United States Government nor any agency thereof, nor Battelle Memorial Institute, nor any of their employees, makes any warranty, express or implied, or assumes any legal liability or responsibility for the accuracy, completeness, or usefulness of any information, apparatus, product, or process disclosed, or represents that its use would not infringe privately owned rights. Reference herein to any specific commercial product, process, or service by trade name, trademark, manufacturer, or otherwise does not necessarily constitute or imply its endorsement, recommendation, or favoring by the United States Government or any agency thereof, or Battelle Memorial Institute. The views and opinions of authors expressed herein do not necessarily state or reflect those of the United States Government or any agency thereof.

PACIFIC NORTHWEST NATIONAL LABORATORY

operated by

BATTELLE

for the

UNITED STATES DEPARTMENT OF ENERGY

under Contract DE-AC06-76RL01830 


\section{TECHNICAL REPORT STANDARD TITLE PAGE}

\begin{tabular}{|c|c|c|c|c|}
\hline \multicolumn{3}{|l|}{$\begin{array}{l}\text { 1. REPORT NO. } \\
\text { WA-RD } 525.1\end{array}$} & \multicolumn{2}{|c|}{ 3. RECIPIENT'S CATALOG NO. } \\
\hline \multicolumn{3}{|l|}{ 4. TITLE AND SUBTITLE } & \multicolumn{2}{|l|}{ 5. REPORT DATE } \\
\hline \multirow{2}{*}{\multicolumn{3}{|c|}{ Evaluation of Methods to Increase Light Under Ferry Terminals }} & \multicolumn{2}{|c|}{ January 2002} \\
\hline & & & \multicolumn{2}{|c|}{ 6. PERFORMING ORGANIZATION CODE } \\
\hline \multicolumn{3}{|c|}{$\begin{array}{l}\text { 7. AUTHOR(S) } \\
\text { Authors: S.L. Blanton, R.M. Thom, A.B. Borde, H. Diefenderfer, } \\
\text { and J.A. Southard }\end{array}$} & \multicolumn{2}{|c|}{$\begin{array}{l}\text { 8. PERFORMING ORGANIZATION REPORT NO. } \\
\text { PNNL-13714 }\end{array}$} \\
\hline \multirow{2}{*}{\multicolumn{3}{|c|}{$\begin{array}{l}\text { 9. PERFORMING ORGANIZATION NAME AND ADDRESS } \\
\text { Battelle, Pacific Northwest Division of Battelle Memorial Institute }\end{array}$}} & \multicolumn{2}{|l|}{ 10. WORK UNIT NO. } \\
\hline & & & \multicolumn{2}{|c|}{ 11. CONTRACT OR GRANT NO. } \\
\hline \multicolumn{3}{|c|}{ 12. SPONSORING AGENCY NAME AND ADDRESS } & \multicolumn{2}{|c|}{ 13. TYPE OF REPORT AND PERIOD COVERED } \\
\hline \multicolumn{3}{|l|}{ Research Office } & \multicolumn{2}{|c|}{ Final Research Report } \\
\hline \multicolumn{5}{|c|}{$\begin{array}{l}\text { Washington State Department of Transportation } \\
\text { Transportation Building, MS } 7370\end{array}$} \\
\hline \multicolumn{3}{|c|}{$\begin{array}{l}\text { Olympia, Washington 98504-7370 } \\
\text { Program Manager: Jim Schafer 360-705-7971 }\end{array}$} & \multicolumn{2}{|c|}{$\begin{array}{l}\text { 14. SPONSORING AGENCY CODE } \\
\end{array}$} \\
\hline \multicolumn{5}{|c|}{$\begin{array}{l}\text { 15. SUPPLEMENTARY NOTES } \\
\text { This study was conducted in cooperation with the U.S. Department of Transportation, Federal } \\
\text { Highway Administration and with the Northwest Maritime Center, Port Townsend, Washington. }\end{array}$} \\
\hline \multirow{2}{*}{\multicolumn{5}{|c|}{$\begin{array}{l}\text { 16. ABSTRACT } \\
\text { To address concerns of resource agencies about the potential impacts of ferry terminal expansion on valuable } \\
\text { habitat functions and resource use of nearshore areas, the Pacific Northwest National Laboratory (PNNL), in } \\
\text { partnership with the Washington State Department of Transportation (WSDOT), conducted field trials with off- } \\
\text { the-shelf products that promote light passage through dock structures. These products included a SunTunnel }{ }^{\mathrm{TM}} \text {, } \\
\text { deck prisms, and a metal halide greenhouse light. Light measurements (photosynthetically active radiation, } \\
\text { PAR) were also recorded beneath glass blocks and a metal grating installed at Clinton Ferry Terminal on } \\
\text { Whidbey Island, Washington. A review of other studies measuring the effects of dock shading and alternate } \\
\text { dock materials was conducted. } \\
\text { PAR measurements from this study were related to minimum requirements for eelgrass Zostera marina } \\
\text { photosynthesis and to the known maximum photosynthetic "saturation" rate for } Z \text {. marina. We also related PAR } \\
\text { measurements to what we know about light requirements for macroalgae and kelp, and light effects on juvenile } \\
\text { salmonid feeding and passage under overwater structures. All of the light technologies tested could provide } \\
\text { enough light for eelgrass growth underneath a ferry terminal that is being expanded or rebuilt if certain } \\
\text { requirements are met. For example, all of the technologies (some singly and some in multiples of two to four) } \\
\text { would provide adequate light for eelgrass if the dock is no greater than } 3 \text { m (10 ft) above the eelgrass. At } \\
\text { increased distances between the deck and eelgrass, the water:air ratio and total distance light must travel begin to } \\
\text { limit the technologies that could successfully be applied. In general, the products predicted to provide the most } \\
\text { to the least light to eelgrass are the grating, SunTunnel, metal halide greenhouse light, and prisms. Light levels } \\
\text { required to allow fish to feed and to form schools are low ( } 1-2 \mu \text { mol } / \mathrm{m}^{2} / \mathrm{s} \text { ), and much less than those required } \\
\text { for photosynthesis (Ali } 1959 \text { ). Based on Ali's data, our research indicates that installing any of the tested light } \\
\text { products would likely maintain light levels under the dock above those required for active feeding by juvenile } \\
\text { salmonids }\end{array}$}} \\
\hline & & & & \\
\hline \multicolumn{2}{|c|}{$\begin{array}{l}\text { Key words: light; overwater structure; nearshore } \\
\text { habitat; photosynthesis; salmonids; eelgrass }\end{array}$} & \multicolumn{3}{|c|}{$\begin{array}{l}\text { No restrictions. This document is available to the } \\
\text { public through the National Technical Information } \\
\text { Service, Springfield, VA } 22616\end{array}$} \\
\hline $\begin{array}{l}\text { 19. SECURITY CLASSIF. (of this report) } \\
\text { ii } \quad \text { None }\end{array}$ & 20. SECURITY CLASSIF. (of & & 21. NO. OF PAGES & 22. PRICE \\
\hline
\end{tabular}




\section{Contents}

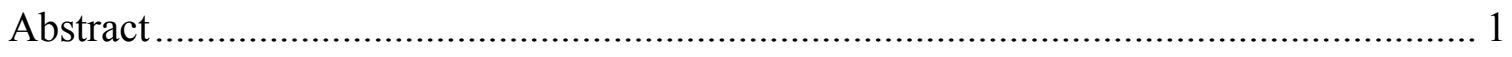

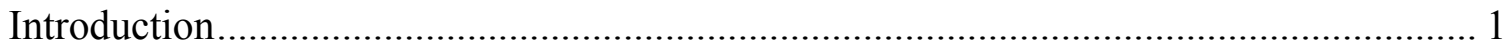

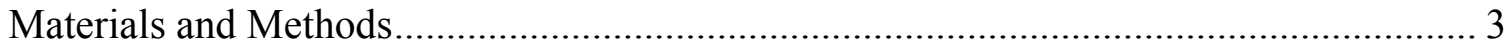

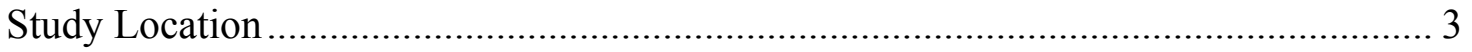

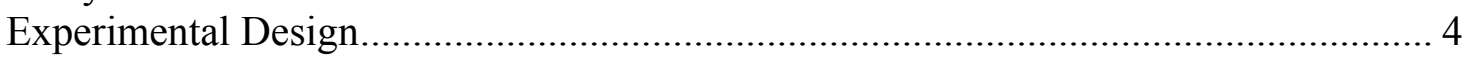

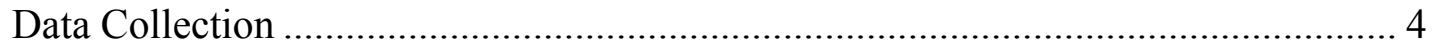

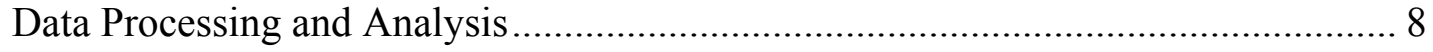

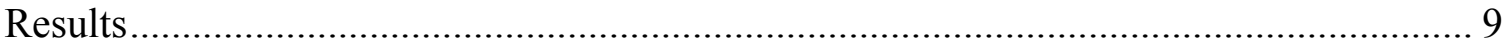

Measurements in Lightproof Structure ...................................................................... 9

Light Product PAR Estimates for Clinton Ferry Terminal .................................... 12

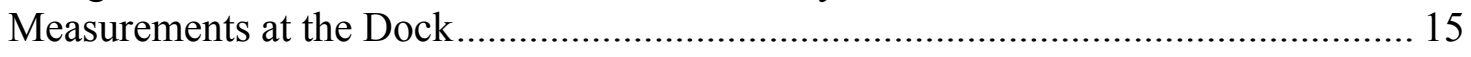

Glass Blocks and Grating at Clinton Ferry Terminal ................................................ 16

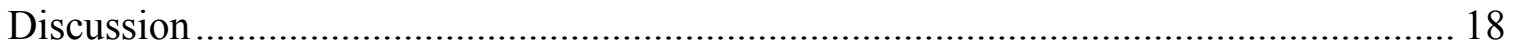

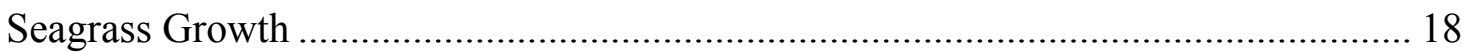

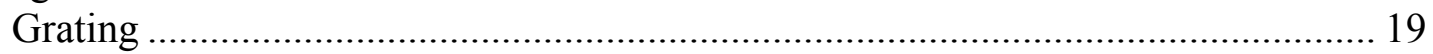

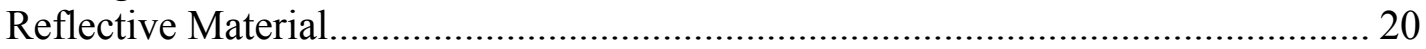

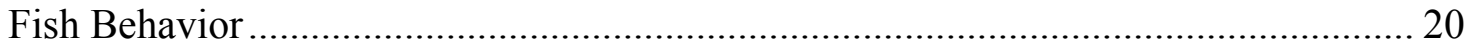

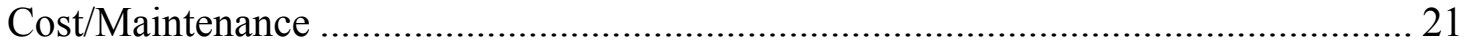

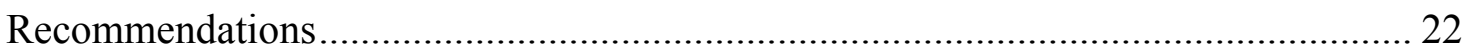

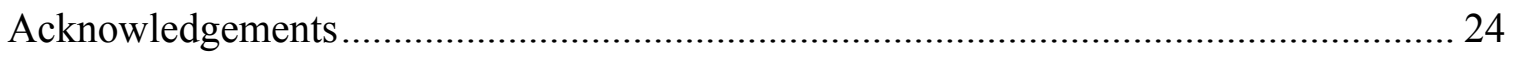

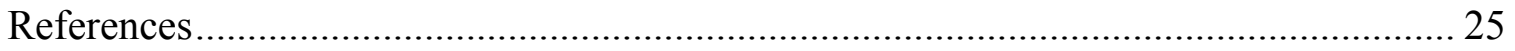

\section{Figures}

Figure 1. Map showing relative locations of the lightproof structure, Thomas Oil

Dock, and Clinton Ferry Terminal. ............................................................

Figure 2. (a) Lightproof structure under construction. The basic structure is on the left and the SunTunnel extension, already wrapped in polyethylene, is on the right; (b) Completed lightproof structure with SunTunnel attached; (c) Upward view through $3 \mathrm{~m}(10 \mathrm{ft})$ of SunTunnel reflective tubing. ..................... 4

Figure 3. Deck prism in stainless steel housing ..........................................................

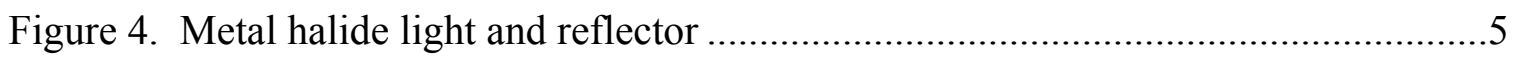

Figure 5. Spherical quantum PAR sensor by LI-COR ..................................................6

Figure 6. LI-COR data logger and diffusion sampling stations (white marks on the floor) inside the lightproof structure. ……………………….............................6

Figure 7. (a) Sun Tunnel installed at the existing dock in Port Townsend, Washington; (b) Measuring light under the dock............................................... 
Figure 8. Deck grating from above (a) and below (b) (note the sun/shade pattern on the water surface).

Figure 9. Glass blocks in the Clinton Ferry Terminal's pedestrian walkway. (a) View from under the dock; (b) Measuring PAR above the blocks but under the glass roof; and (c) Close-up of glass blocks. 7

Figure 10. Light attenuation curves for light products tested in the lightproof structure.

Figure 11. Mean light (PAR) measured at 0.3-0.6 m (1-2 ft) from the light source inside the lightproof structure. (a) mean ambient PAR for all days data were collected; (b) the SunTunnel, 1 prism, and 3 prisms.

Figure 12. Light diffusion patterns for light products tested in the lightproof structure.

Figure 13. Amount of grating required to achieve $3 \mathrm{~mol} /$ day in 8 hours

Figure 14. Number of SunTunnels (a) and metal halide grow lights (b) required to achieve $3 \mathrm{~mol} /$ day in 8 hours.

Figure 15. Number of prisms required to achieve $3 \mathrm{~mol} /$ day in 8 hours

Figure 16. Light Attenuation Curves for Light Products Tested at the Thomas Oil Dock, Port Townsend, Washington. 15

Figure 17. Instantaneous light patterns measured in air $1.5 \mathrm{~m}(5 \mathrm{ft})$ under the deck prism at Thomas Oil Dock, Port Townsend, Washington at (a) $1300 \mathrm{hrs}$ and (b) $1650 \mathrm{hrs}$. Mean light diffusion patterns for all samplings for the (c) SunTunnel and (d) Deck Prism tested at the Thomas Oil Dock.

Figure 18. Light transects under the Clinton Ferry Terminal, showing average in-air PAR in 2000 (without glass blocks) and in 2001 (with glass blocks).

\section{Tables}

Table 1. Percent ambient light $\left(\mu \mathrm{mol} / \mathrm{m}^{2} / \mathrm{s}\right)$ at 1 and 10 feet from the light source.

Table 2. Estimated light levels reaching the water surface and eelgrass at the Clinton Ferry Terminal (assuming light travels through $1 \mathrm{~m}(3.4 \mathrm{ft})$ of air and $2.8 \mathrm{~m}$ $(9.1 \mathrm{ft})$ of water).

Table 3. Light measured over the glass blocks along the pedestrian walkway at Clinton Ferry Terminal compared to ambient light levels. 17

Table 4. Costs and benefits associated with lighting products. 


\section{Abstract}

To address concerns of resource agencies about the potential impacts of ferry terminal expansion on valuable habitat functions and resource use of nearshore areas, the Pacific Northwest National Laboratory (PNNL), in partnership with the Washington State Department of Transportation (WSDOT), conducted field trials with off-the-shelf products that promote light passage through dock structures. These products included a SunTunnel ${ }^{\mathrm{TM}}$, deck prisms, and a metal halide greenhouse light. Light measurements (photosynthetically active radiation, PAR) were also recorded beneath glass blocks and a metal grating installed at Clinton Ferry Terminal on Whidbey Island, Washington. A review of other studies measuring the effects of dock shading and alternate dock materials was conducted.

PAR measurements from this study were related to minimum requirements for eelgrass Zostera marina photosynthesis and to the known maximum photosynthetic "saturation" rate for Z. marina. We also related PAR measurements to what we know about light requirements for macroalgae and kelp, and light effects on juvenile salmonid feeding and passage under overwater structures. All of the light technologies tested could provide enough light for eelgrass growth underneath a ferry terminal that is being expanded or rebuilt if certain requirements are met. For example, all of the technologies (some singly and some in multiples of two to four) would provide adequate light for eelgrass if the dock is no greater than $3 \mathrm{~m}(10 \mathrm{ft})$ above the eelgrass. At increased distances between the deck and eelgrass, the water:air ratio and total distance light must travel begin to limit the technologies that could successfully be applied. In general, the products predicted to provide the most to the least light to eelgrass are the grating, SunTunnel, metal halide greenhouse light, and

prisms. Light levels required to allow fish to feed and to form schools are low $\left(\sim 1-2 \mu \mathrm{mol} / \mathrm{m}^{2} / \mathrm{s}\right)$, and much less than those required for photosynthesis (Ali 1959). Based on Ali's data, our research indicates that installing any of the tested light products would likely maintain light levels under the dock above those required for active feeding by juvenile salmonids.

\section{Introduction}

There are important reasons to minimize the shading effects of over-water structures, such as ferry terminal docks. Shading may result in a variety of ecological consequences including loss of submerged aquatic vegetation (e.g., eelgrass Zostera marina), alteration of habitat used by juvenile salmon, potential loss of salmon prey resources, and potential interruption of fish migratory patterns (Pentilla and Doty, 1990; Simenstad et al. 1999). The main driver behind reducing shading along the nearshore in Washington is the need to reduce potential adverse impacts to juvenile salmon populations. Many of Puget Sound's ocean-type salmon populations rely on estuarine and nearshore environments for feeding and refuge during their early life. This period is associated with the early entry of fry and fingerlings 30-80 mm (1.2-3.1 inches) in length into Puget Sound after no or brief residence in their natal freshwater spawning sites. Species that migrate early as fry or fingerlings include chinook, chum, and pink salmon. Two of these Puget Sound salmon stocks, chinook and summer chum, are federally listed under the Endangered Species Act (ESA), as is Puget Sound chinook critical habitat, which includes eelgrass beds.

Juvenile salmon may encounter limited prey resources under shoreline structures if important habitats such as eelgrass beds are disturbed. Light energy drives the plant photosynthetic process, and modifications to light (and also temperature, salinity, nutrient levels, and wave action) beneath 
overwater structures can influence the rate of photosynthesis, plant distribution, and survival of eelgrass and algae that directly or indirectly (through detritus trapping) support prey resource composition and production. Nearshore bands of eelgrass have been identified as a particularly important prey resource habitat for juvenile salmonids, as they provide refuge and are a major primary production source of organic matter for the nearshore, detritus-based food web (Simenstad 1994). Any structure that interferes with the availability of light to this ecosystem is likely to decrease the production of critical plant material basic to this copepod-salmonid food web system.

There are no natural analogs to large overwater structures, such as ferry terminals, to which salmon have adapted during the evolution of their early life history patterns (Simenstad et al. 1999). In general, salmon fry tend to use both natural cover (e.g. vegetation such as Z. marina) and darkness (e.g. shading from docks and floats) as refuge, but migrate along these edges rather than penetrate them. Consequently, juvenile salmon in Puget Sound have been observed to alter their behavior upon encountering docks (Simenstad et al. 1999). Salmon behavior responses to light variations are based on the difference between the ambient light level to which the fish has been exposed before it encounters any changes in the quality or intensity of light caused by an over-water structure. Docks can create sharp underwater contrasts by casting shade under ambient daylight conditions, which may, at times, deter juvenile salmon from passing from light to dark water (Southard and Blanton, personal observations).

Resource agencies are concerned that ferry terminal expansion projects will further impact habitat functions and resource use of nearshore areas. Of the 19 Washington State Ferry (WSF) terminals, eight have documented eelgrass beds in the nearshore vicinity. These terminals are generally at least $30 \mathrm{~m}$ (98 ft) wide and extend out from the shoreline across shallow areas dominated by eelgrass, algae, and nearshore habitat used by salmon. The Washington State Department of Transportation (WSDOT) is concerned about Department programs that may affect Pacific salmon and their habitats under the ESA. Accordingly, in partnership with WSDOT, the Pacific Northwest National Laboratory (PNNL) conducted field trials with off-the-shelf products that promoted light passage through dock structures to the water below. These products included a SunTunnel ${ }^{\mathrm{TM}}$, deck prisms (i.e., used to pass light into dark places such as rooms on small vessels), and a metal halide greenhouse light. In addition, light measurements were recorded at the Clinton Ferry Terminal on Whidbey Island, Washington where glass blocks had been installed in a pedestrian walkway to allow light to pass through the dock to the water below. A temporary metal grating at the Clinton terminal also allowed light to pass through the dock and its light contribution below the dock was also measured.

Because plants require particular light spectrums to support photosynthetic reproduction and growth, we measured the photosynthetically active radiation (PAR; defined as wavelengths between 400 and $700 \mathrm{~nm}$ ) under the structures. We have related the PAR measurements to the minimum requirements for $Z$. marina photosynthesis and to the known maximum photosynthetic "saturation" rate for $Z$. marina (Duarte 1991; Dennison et al. 1993; Thom 1994, unpublished report; Thom and Shreffler 1996). The latter is the point at which increased irradiance no longer results in increased production. We have also related the PAR measurements to what we know about light requirements for macroalgae and kelp (Lobban et al. 1985, Lüning 1981) and light effects on juvenile salmonid feeding and passage under overwater structures from the review by Simenstad et al. (1999). To provide a more complete assessment of technologies, we also reviewed other studies measuring the effects of dock shading and alternate dock materials. This information can be used directly by WSF Terminal Engineering for incorporation into the planning and design of new docks and the design of existing docks that may be conducted as part of WSF's preservation program. This compilation of information can also be used by WSF to develop mitigative actions for identifiable marine environmental impacts, especially those related to salmon. 


\section{Materials and Methods}

\section{Study Location}

Research on the technologies was conducted at the Battelle Marine Sciences Laboratory (MSL) in Sequim, Washington. A lightproof structure was erected on an east/west-facing dock at the entrance to Sequim Bay where it would not be shaded by buildings or landscape features (Figure 1). Eelgrass meadows are present in the nearshore adjacent to the north side of the dock.

Additional field testing was completed at Thomas Oil Dock in Port Townsend, Washington, which is owned by the Northwest Maritime Center, a non-profit educational organization (Figure 1). This derelict dock extends $71 \mathrm{~m}$ (233 feet) into Port Townsend Bay in a northwest-southeast orientation. Light products were installed in the decking over the region between 3.6 and 4.6 ft MLLW. Eelgrass is present at this site in the vicinity of the dock.

Additional light (i.e., PAR) measurements were recorded at the Clinton Ferry Terminal at the south end of Whidbey Island, Washington (Figure 1). The ferry dock extends over the water in a northeast-southwest orientation. Glass blocks had been installed as flooring in a newly constructed pedestrian walkway in efforts to allow greater light to reach the water surface. Light measurements were recorded above and below the glass blocks, as well as below a metal grating running parallel to and down the center of the dock. Earlier laboratory studies found that 50-60 percent of ambient light passed through the glass blocks (Simenstad et al. 1997).

\section{Lightproof Structure $\theta$ Thomas Oil Dock Clinton Ferry Terminal}

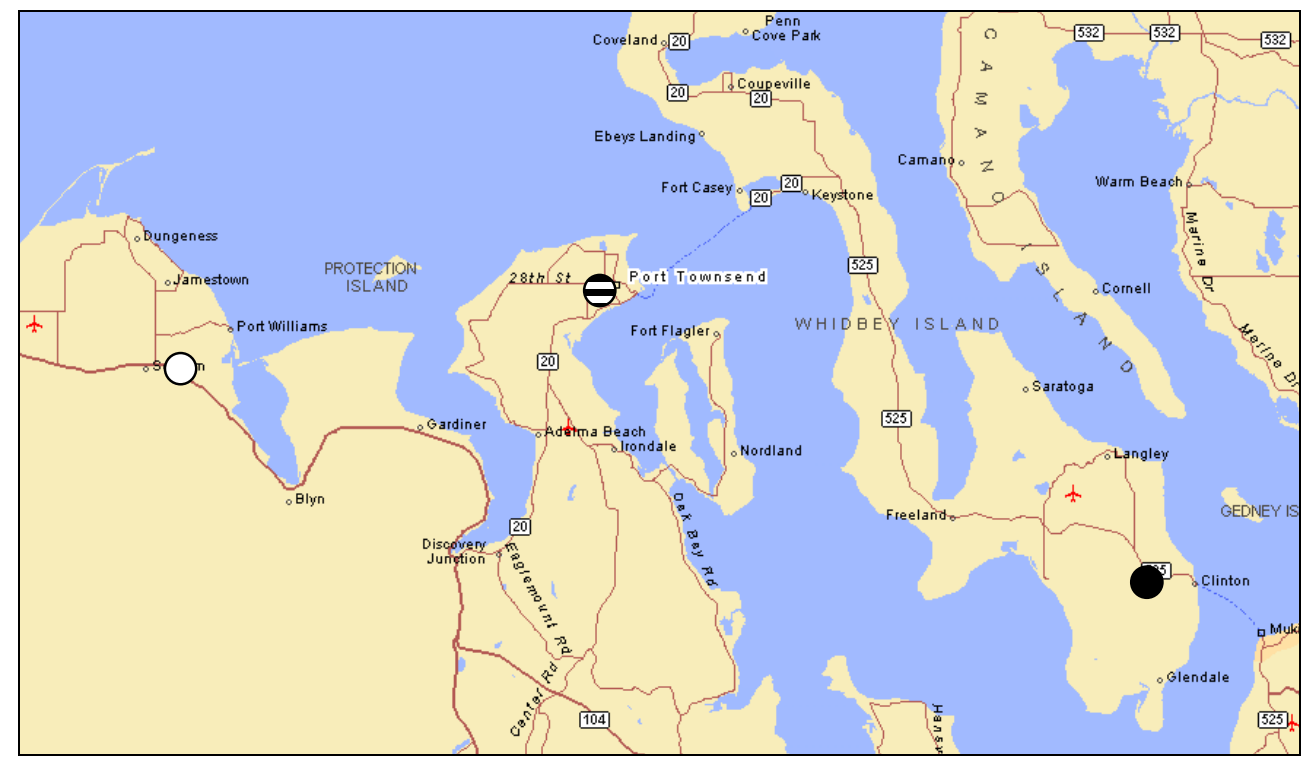

Figure 1. Map showing relative locations of the lightproof structure, Thomas Oil Dock, and Clinton Ferry Terminal. 


\section{Experimental Design}

\section{Data Collection}

The products were installed in a structure designed to block ambient light from entering anywhere except through the product being evaluated. The structure constructed at MSL was $2.4 \mathrm{~m}(8 \mathrm{ft})$ on each side and $3 \mathrm{~m}$ (10 ft) tall. The frame was constructed of fiberglass rigid plastic (FRP), two-byfours, and plywood, then wrapped in two layers of black Visqueen (polyethylene) to block all light. An opening in the plywood at the top of the structure allowed the light products to be interchanged with relative ease. A small door at the bottom allowed a person to enter the structure to access the data logger and light sensor and to record light measurements. When installing the SunTunnel, an additional $3-\mathrm{m}$ tall by $0.8-\mathrm{m}$ square ( $10-\mathrm{ft}$ tall by 2.5 -ft square) frame was attached to the top of the basic structure. This allowed the SunTunnel's reflective tubing to extend vertically $3 \mathrm{~m}(10 \mathrm{ft})$ and light was measured inside the structure, underneath the attachment (Figure 2).
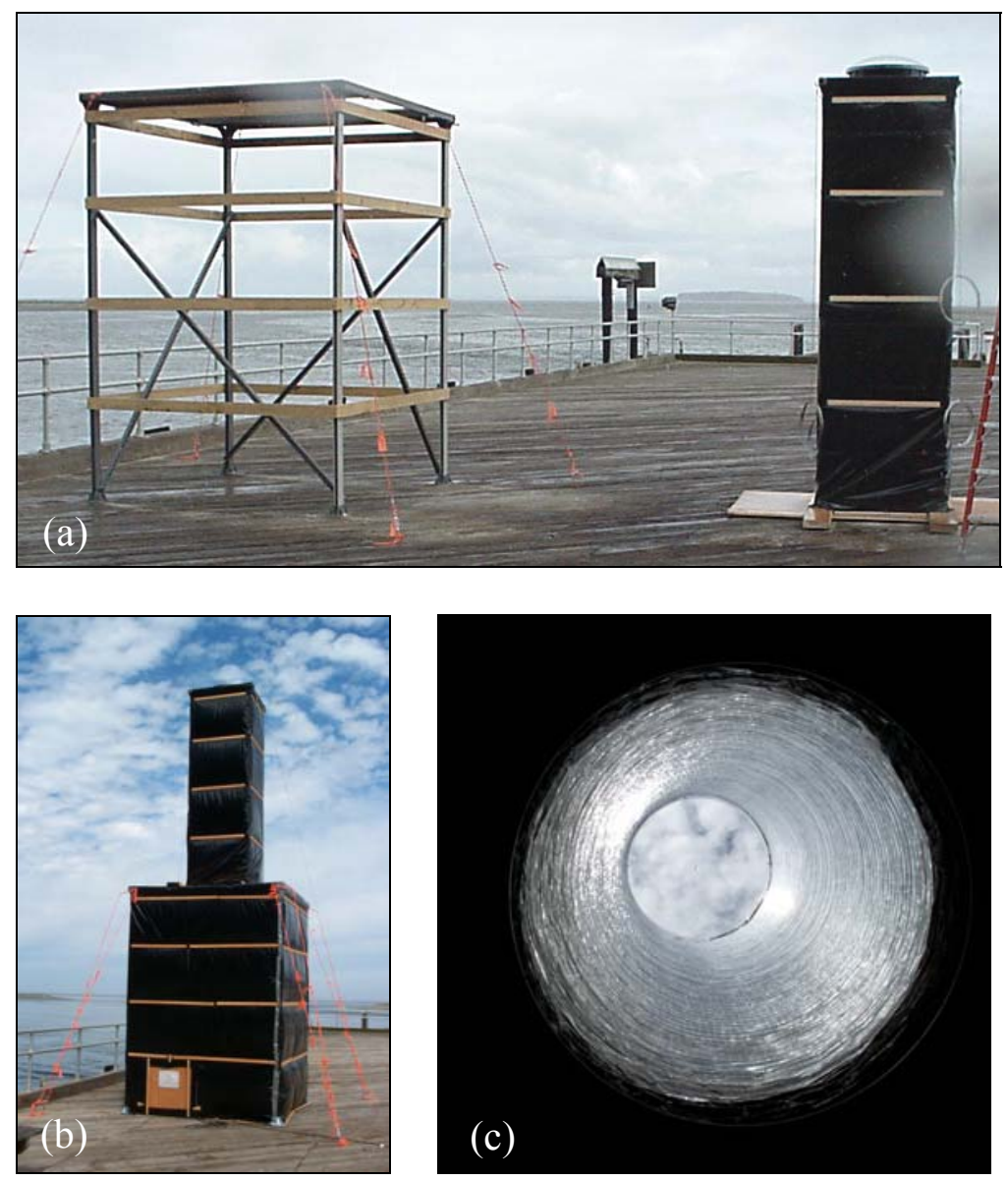

Figure 2. (a) Lightproof structure under construction. The basic structure is on the left and the SunTunnel extension, already wrapped in polyethylene, is on the right; (b) Completed lightproof structure with SunTunnel attached; (c) Upward view through $3 \mathrm{~m} \mathrm{(10} \mathrm{ft)} \mathrm{of} \mathrm{SunTunnel} \mathrm{reflective}$ tubing.

The three products tested included a SunTunnel $\bigcirc$, deck prisms (Figure 3), and a metal halide light with reflector shield (Figure 4). The SunTunnel is marketed as a ventilated roof-to-ceiling skylight system that is easy to install. The SunTunnel has a flexible, reflective tube comprised of highly 
reflective metalized polyester film to propagate light from the sun into recessed spaces. The unit purchased for this study was $0.56 \mathrm{~m}$ (22 inches) in diameter and the flexible tubing was cut to a $3 \mathrm{~m}$ (10 ft) length. At MSL, light passing through the SunTunnel was measured at distances of $0.3 \mathrm{~m}$ and $3 \mathrm{~m}$ (1 ft and $10 \mathrm{ft}$ ) from the bottom of the reflective tube on May 22, 23, 29, 31, and June 1, 2001. Attenuation and diffusion data were collected May 24, 2001. Attenuation and diffusion light measurements with the SunTunnel installed at the Thomas Oil Dock in Port Townsend were recorded July 4, August 13, 14, 29, 31 and September 29, 2001.

The prisms used in this study had an outside measurement of $14 \mathrm{~cm}$ by $32 \mathrm{~cm}(5.5$ inches by 12.5 inches) (Figure 3). Testing was conducted on one prism and on a set of three prisms spaced on $37-\mathrm{cm}$ (14.5-inch) centers with the long sides parallel to each other. The single prism was tested at MSL on June $6,7,25,27$, and 28, 2001, with attenuation and diffusion measurements recorded on June 21, 2001. Three prisms mounted in series were tested June 4, 5, 25, and 26, 2001 with attenuation and diffusion measurements recorded June 20 and 21, 2001. Light through a single prism installed at the Thomas Oil Dock in Port Townsend was measured September 1, 2, and 3, with attenuation and diffusion data collected September 31, 2001.

The metal halide electric light was a Sylvania 1000-watt Metalarc (Figure 4). The metal reflector shield was round and concave, $61 \mathrm{~cm}$ (24 inches) in diameter with a depth of $38 \mathrm{~cm}$ (15 inches). The light was tested at MSL on July 1, 2, 3 and September 28, 2001. Attenuation and diffusion data were collected July 30, 2001.

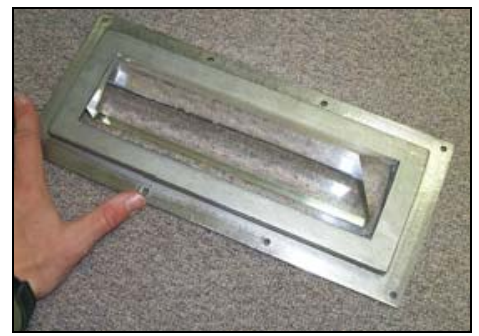

Figure 3. Deck prism in stainless steel housing

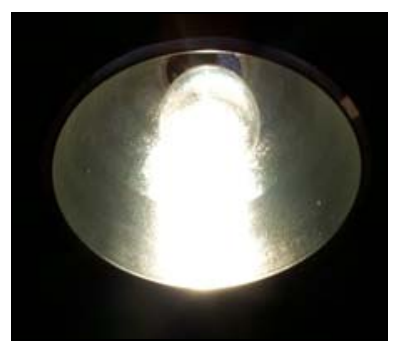

Figure 4. Metal halide light and reflector

Prior to field testing, three types of light measurements were recorded for each product using LI-COR LI-193SA spherical quantum sensors (Figure 5) and a LI-COR LI-1400 Datalogger and associated cables (Figure 6). Light attenuation from the light source to the floor of the lightproof structure was measured in $0.3-\mathrm{m}(1-\mathrm{ft})$ increments. A minimum of 10 attenuation curves was collected for each product tested. The diffusion of light inside the structure was also measured, at a consistent height of

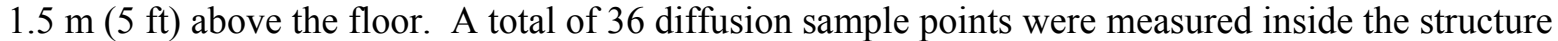
and a minimum of 3 measurement series were recorded at each point at different times of day. Marks placed on the floor of the structure ensured that measurements were recorded in the same positions for every light product (Figure 6). Finally, simultaneous measurements of the amount of light 
entering the lightproof structure 0.3-0.6 $\mathrm{m}(1-2 \mathrm{ft})$ below the light source and the ambient outdoor light were recorded continuously between 1000 and $1500 \mathrm{hrs}$. Data were collected at 5-second intervals then averaged and recorded at 5-min intervals.

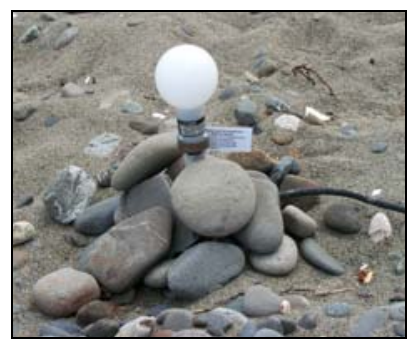

Figure 5. Spherical quantum PAR sensor by LI-COR

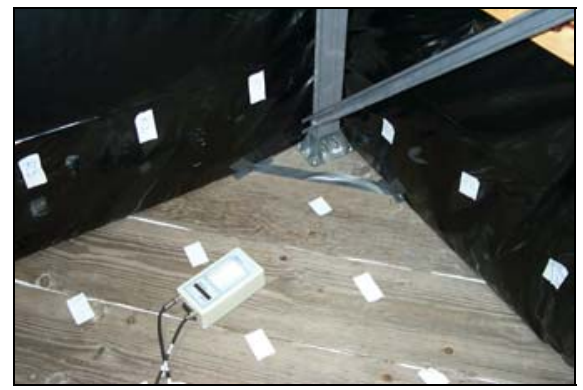

Figure 6. LI-COR data logger and diffusion sampling stations (white marks on the floor) inside the lightproof structure.

After the SunTunnel and deck prisms were evaluated inside the lightproof structure, they were transported to the Port Townsend dock (Figure 7), where they were evaluated using the same LI-COR equipment. The dock is of timber construction with 7.6-cm (3-inch) thick diagonal decking material. The dimensions of the dock were $71 \mathrm{~m}$ long by $3 \mathrm{~m}$ wide $(233 \mathrm{ft}$ by $10 \mathrm{ft})$. The water surface

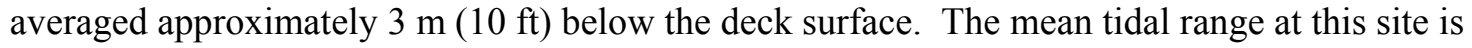
approximately $1.61 \mathrm{~m}(5.3 \mathrm{ft})$. The SunTunnel extension (still wrapped in polyethylene) and a deck prism were mounted in turn over a hole cut in the decking. Light attenuation at $0.3-\mathrm{m}(1-\mathrm{ft})$ intervals, diffusion, and simultaneous measurements of ambient light and light beneath the light product were measured at this location. Attenuation data were collected from immediately below the light product to $3 \mathrm{~m} \mathrm{(10} \mathrm{ft)} \mathrm{below} \mathrm{the} \mathrm{water} \mathrm{surface,} \mathrm{which} \mathrm{at} \mathrm{some} \mathrm{tides} \mathrm{reached} \mathrm{the} \mathrm{substrate.} \mathrm{Because} \mathrm{many} \mathrm{of}$ the measurements to determine light attenuation and diffusion had to be taken over water, kayaks were employed.
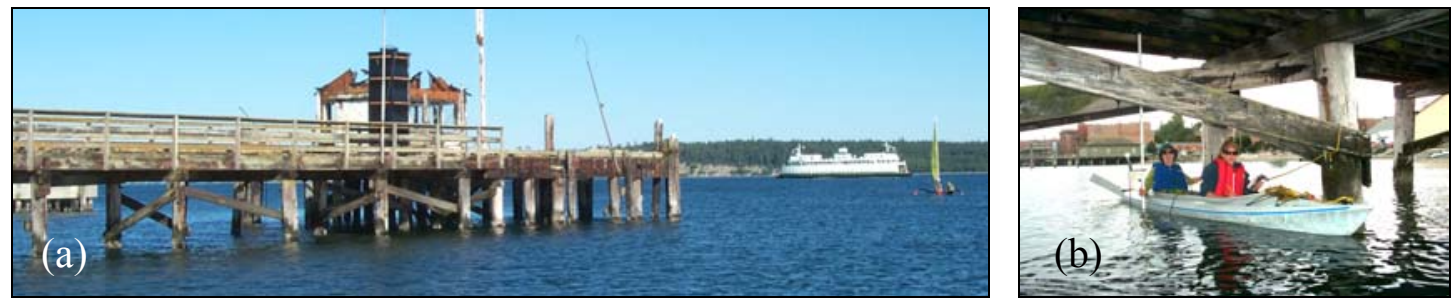

Figure 7. (a) Sun Tunnel installed at the existing dock in Port Townsend, Washington; (b) Measuring light under the dock.

To measure the effects of light through alternative materials (i.e., glass blocks and metal grating), light measurements along transects under the Clinton Ferry Terminal were conducted using the same LI-COR equipment. The grating (Figure 8) was present in 2000 and 2001, but the glass blocks 
(Figure 9) were only present in 2001. Previously, the glass blocks were covered with solid sheets of plywood because of construction activities at the terminal. Because light data were collected both years, a comparison of light penetration under the dock with and without the glass blocks was possible.

At the Clinton Ferry Terminal, light profiles were recorded along transects along the $0 \mathrm{ft}$ MLLW depth contour that began $10 \mathrm{~m}(33 \mathrm{ft})$ south of the dock and extended at least $35 \mathrm{~m} \mathrm{(115 \textrm {ft } )}$ underneath the dock and beyond the influence of the metal grating installed on deck. The deck is

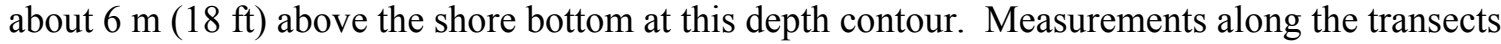
were recorded in air. Additional light measurements were recorded over the glass blocks both underneath the glass roof (Figure 9) and in ambient light that did not pass through the glass roof. Finally, attenuation profiles were recorded in water by measuring PAR data just above the water surface, just below the water surface, and at $0.5-\mathrm{m}(1.6-\mathrm{ft})$ interval depths under water. The PAR sensor was either lowered over the side of the dock or over the side of a canoe where the sensor was not shaded.
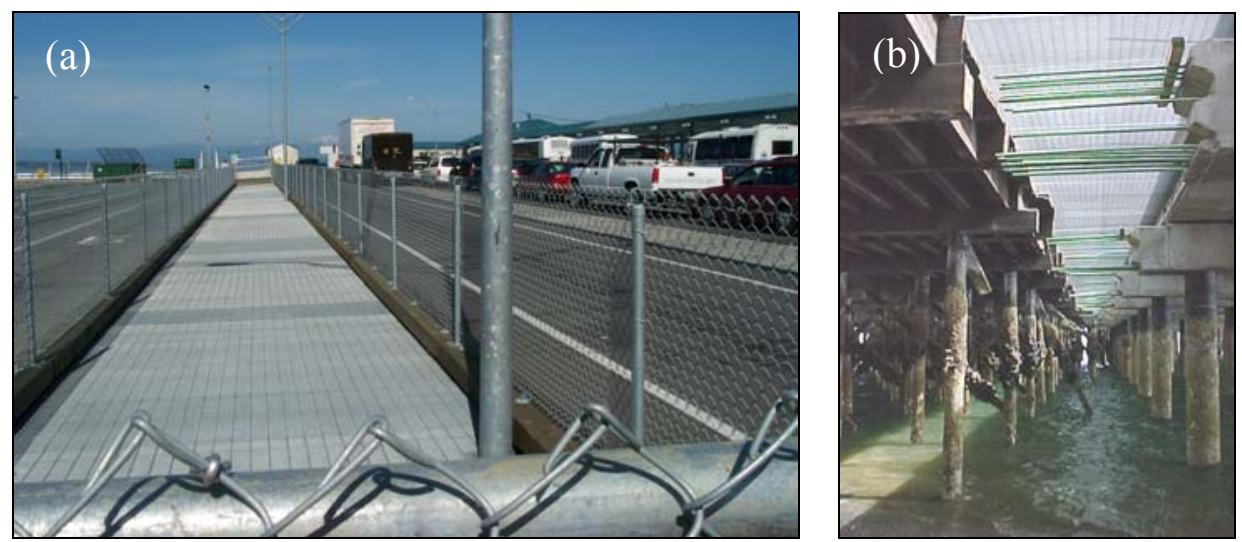

Figure 8. Deck grating from above (a) and below (b) (note the sun/shade pattern on the water surface).
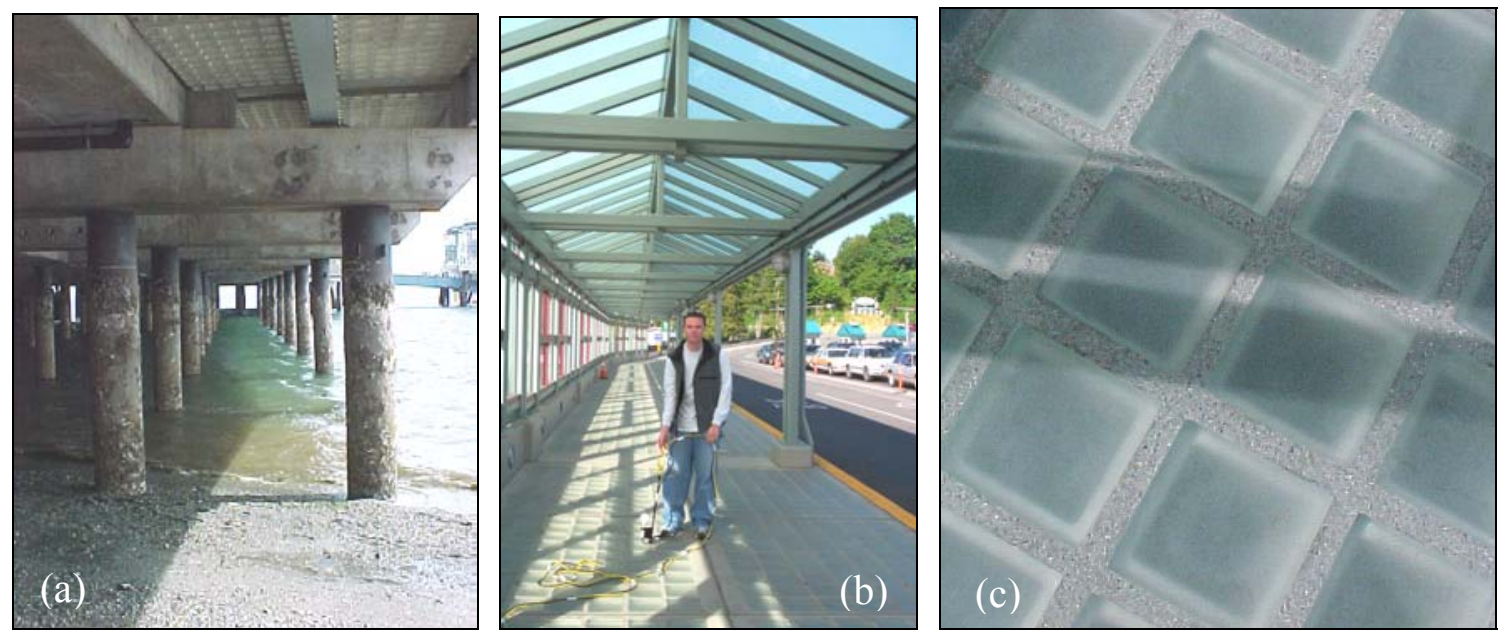

Figure 9. Glass blocks in the Clinton Ferry Terminal's pedestrian walkway. (a) View from under the dock; (b) Measuring PAR above the blocks but under the glass roof; and (c) Close-up of glass blocks. 


\section{Data Processing and Analysis}

All light data collected in the field were transcribed to Microsoft Excel files. Continuous data collected with the LI-1400 Datalogger at MSL and in Port Townsend were downloaded directly through an RS-222 serial port to a computer and saved as Microsoft Excel files. The percent of ambient light at several discrete distances from the light source was calculated for each five-minute sampling period by comparing the simultaneous measurements inside and outside the lightproof structure. Light output for each light product was analyzed using analysis of variance (ANOVA). All tests of statistical significance were reported at the $"=0.05$ level. When significant differences were detected, a Tukey multiple comparison procedure was undertaken to determine more precisely where the differences occurred. 


\section{Results}

\section{Measurements in Lightproof Structure}

Light measurements recorded inside the lightproof structure indicate that the metal halide light was most effective at transmitting PAR. The light attenuation curves (Figure 10) and measurements of light intensity compared to ambient light conditions outside the lightproof structure (Figure 11) clearly show this effect. The SunTunnel provided the next greatest amount of light, but at levels approximately 12.5 percent of the metal halide light.

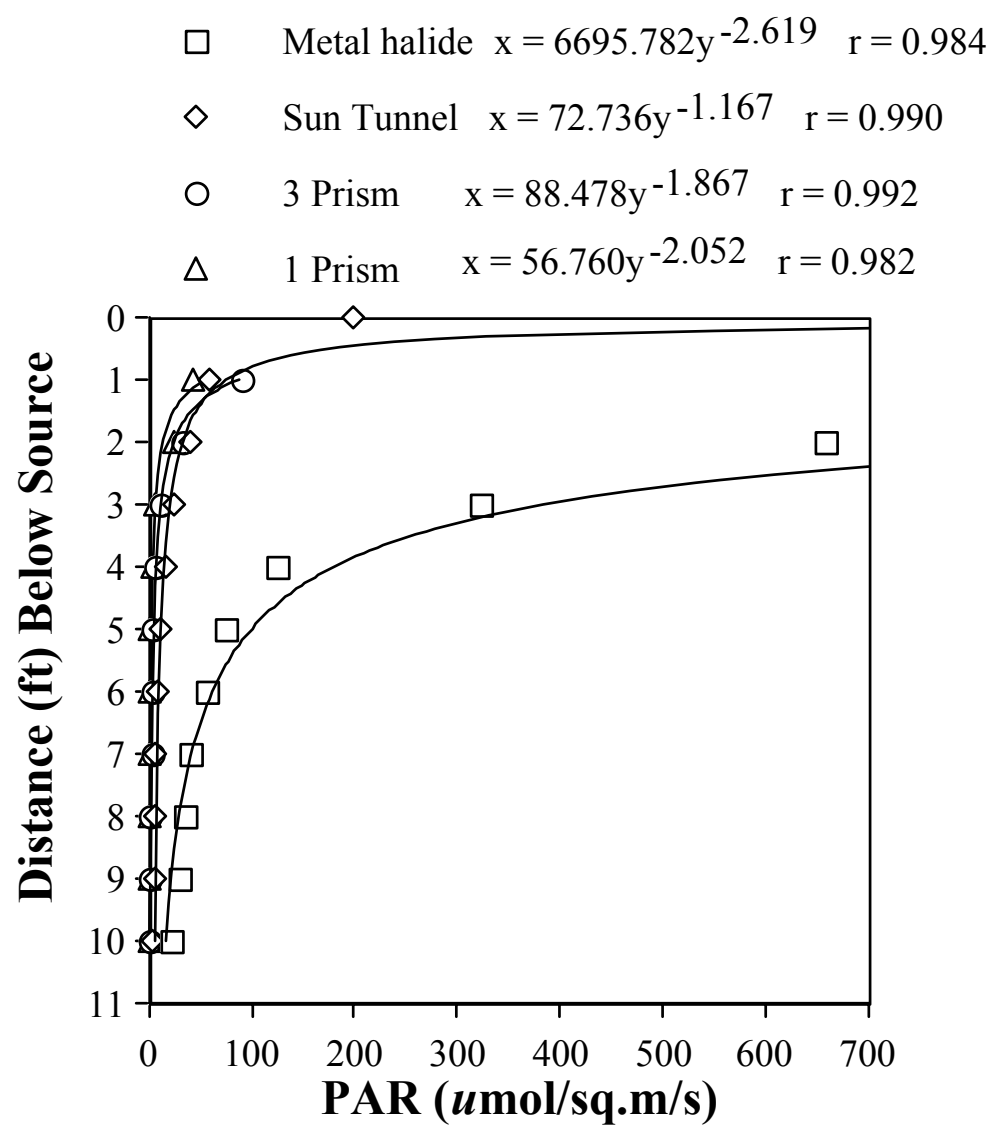

Figure 10. Light attenuation curves for light products tested in the lightproof structure. 

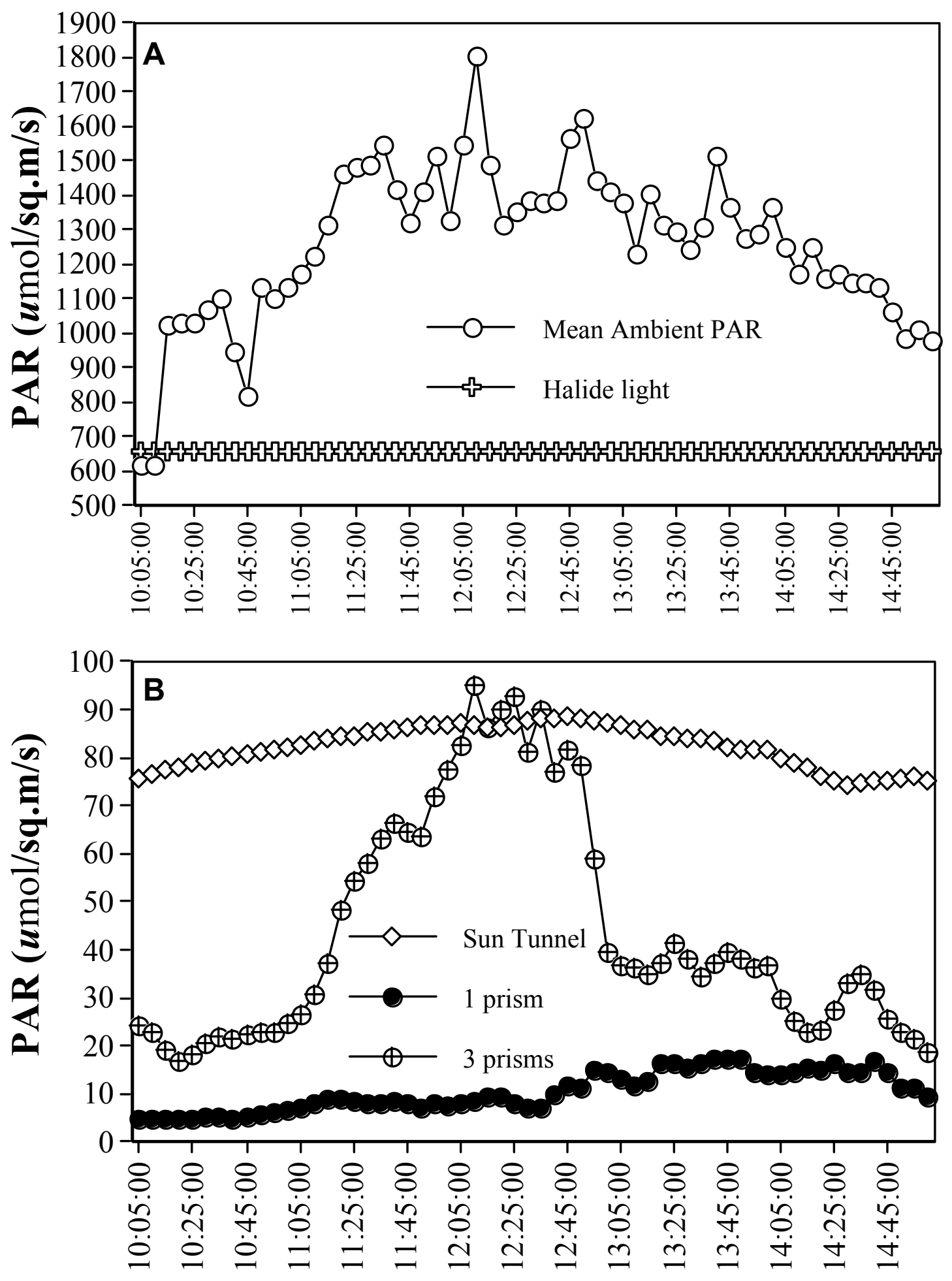

Time

Figure 11. Mean light (PAR) measured at 0.3-0.6 m (1-2 ft) from the light source inside the lightproof structure. (a) mean ambient PAR for all days data were collected; (b) the SunTunnel, 1 prism, and 3 prisms. 
The relative amount of light reduction due to light passage through the SunTunnel and prisms was calculated for each using the difference between measurements made inside the lightproof structure and ambient light. Light data were logged continuously onto the same data logger inside and outside the lightproof structure between 1000 and $1500 \mathrm{hrs}$. Calculating the mean percent ambient PAR for 10 replicate runs for each technology using the equation

$$
\text { Mean percent of light transmitted or produced }=((\Sigma P A R \text { inside } / \Sigma P A R \text { ambient }) \times 100) \div 10
$$

shows that the most light was produced by the metal halide light, followed by the SunTunnel, three prisms, and one prism (Table 1). At one foot from the light source, the SunTunnel provided a greater percent ambient light than did the prisms (means of $75.8,44.0$, and $10.5 \mu \mathrm{mol} / \mathrm{m}^{2} / \mathrm{s}$, for the SunTunnel, three prisms and one prism, respectively). The metal halide light was so bright at one foot from the light source that the PAR sensor "maxed out" at 19,999 $\mu \mathrm{mol} / \mathrm{m}^{2} / \mathrm{s}$. At $10 \mathrm{ft}$ from the light source, the metal halide light provided the greatest PAR of all the technologies with an average of $26.4 \mu \mathrm{mol} / \mathrm{m}^{2} / \mathrm{s}$. The SunTunnel ranked second (averaging $4.5 \mu \mathrm{mol} / \mathrm{m}^{2} / \mathrm{s}$ ), at just $17 \%$ of the light passed by the metal halide light $((0.18 / 1.07) * 100)$. The prisms averaged 2.2 and $0.52 \mu \mathrm{mol} / \mathrm{m}^{2} / \mathrm{s}$ for three prisms and one prism, respectively. The amount of ambient light passed by three prisms and one prism was never significantly different although the means differed considerably.

Table 1. Percent ambient light $\left(\mu \mathrm{mol} / \mathrm{m}^{2} / \mathrm{s}\right)$ at 1 and 10 feet from the light source.

\begin{tabular}{lcc}
\hline \multicolumn{1}{c}{ Technology } & Mean Percent Ambient PAR & Distance from Light Source (ft) \\
\hline Metal Halide Light & $>100$ & 1 \\
SunTunnel* & 5.70 & 1 \\
3 Prisms & 2.74 & 1 \\
1 Prism & 1.38 & 1 \\
\hline Metal Halide Light & 1.07 & 10 \\
SunTunnel* & 0.18 & 10 \\
3 Prisms & 0.10 & 10 \\
1 Prism & 0.03 & 10 \\
\hline
\end{tabular}

*The SunTunnel was constructed with a 3-m (10-ft) reflective tube.

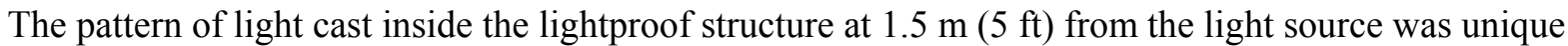
for each lighting product. Light passing through the deck prism(s) was highly spatially variable, depending on the angle of the sun (Figure 12, a and b). Several small rainbows of intense light were generally observed at all times during the day, but their locations appeared to shift in an unpredictable manner. No single area received consistent light over time. As expected, the SunTunnel produced a concentrated beam of light directly under the reflective tubing (Figure 12, c). In direct contrast with the SunTunnel, light from the metal halide lamp and reflector shield was concentrated at the outer edges of the lightproof structure (Figure 12, d). Even in the relatively dark center of the metal halide light diffusion pattern, PAR was, on average, approximately 10 times greater than the brightest central region measured under the SunTunnel. 


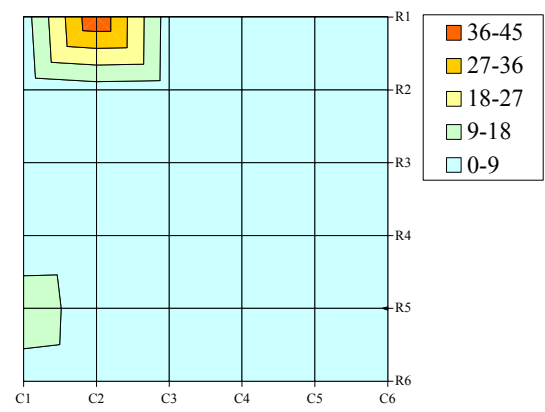

(a) 1 PRISM

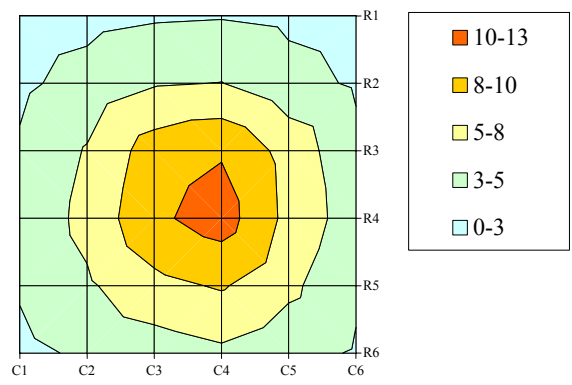

(c) SUNTUNNEL

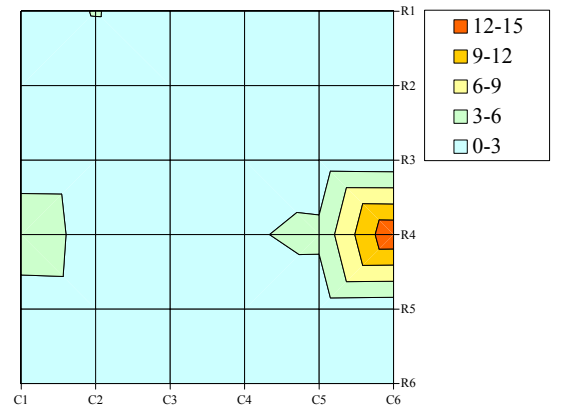

(b) 3 PRISMS

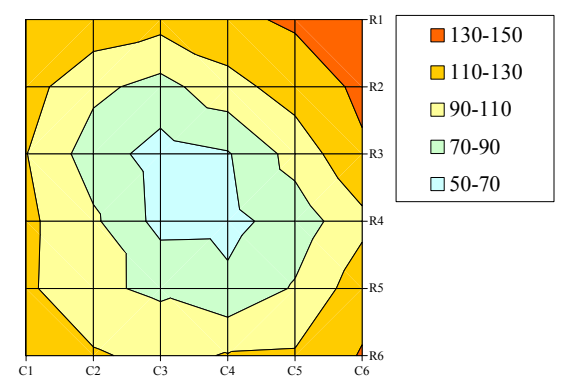

(d) METAL HALIDE LIGHT

Figure 12. Light diffusion patterns for light products tested in the lightproof structure. Values are $\operatorname{PAR}\left(\mu \mathrm{mol} / \mathrm{m}^{2} / \mathrm{s}\right)$.

\section{Light Product PAR Estimates for Clinton Ferry Terminal}

Because new lighting products may someday be retrofitted to existing ferry terminals, the effectiveness of the various technologies was calculated as though they were installed at the Clinton Ferry Terminal where the deck was approximately $3.8 \mathrm{~m}(12.5 \mathrm{ft})$ above the water surface. Light data collected at the Clinton site in 2000 and 2001 were used to calculate a mean attenuation coefficient, $\mathrm{K}_{\mathrm{d}}$, of 0.47, using the equation from Kirk (1994).

where $E_{d}=$ downward irradiance,

$$
\ln E_{\mathrm{d}}(z)-\ln E_{\mathrm{d}}(0)=-K_{\mathrm{d}} z
$$

$z=$ depth in meters, and

$K_{d}=$ light attenuation coefficient

The amount of light reaching eelgrass was then calculated based on assumptions about the dock height, mean tide level, and mean depth of existing eelgrass. The attenuation of light through $1 \mathrm{~m}$ $(3.4 \mathrm{ft})$ of air after passing through the various light products allowed 16 to 50 percent of ambient light to reach the water surface (Table 2). After traveling through $9.1 \mathrm{ft}$ of water to $-2.5 \mathrm{ft}$ MLLW, the mean depth of eelgrass at the Clinton site, enough light could be provided to saturate eelgrass photosynthesis on a sunny day. 
Table 2. Estimated light levels reaching the water surface and eelgrass at the Clinton Ferry Terminal (assuming light travels through $1 \mathrm{~m}(3.4 \mathrm{ft})$ of air and $2.8 \mathrm{~m}(9.1 \mathrm{ft})$ of water).

\begin{tabular}{|c|c|c|c|c|c|c|c|}
\hline $\begin{array}{c}\text { Ambient } \\
\text { Light (PAR) }\end{array}$ & Light Source & $\begin{array}{c}\text { Light Reaching } \\
\text { Water Surface } \\
\text { (PAR) }\end{array}$ & $\begin{array}{c}\text { Percent } \\
\text { Ambient PAR } \\
\text { Reaching Water } \\
\text { Surface }\end{array}$ & $\begin{array}{l}\text { Light Reaching } \\
\text { Mean Eelgrass } \\
\text { Depth of }-2.5 \mathrm{ft} \\
\text { MLLW (PAR) }\end{array}$ & $\begin{array}{c}\text { Percent of } \\
\text { Ambient PAR } \\
\text { at Mean } \\
\text { Eelgrass Depth }\end{array}$ & $\begin{array}{c}\text { Hours at this } \\
\text { Light } \\
\text { Level/Day to } \\
\text { Achieve } 3 \\
\text { mol }^{\text {(a) }}\end{array}$ & $\begin{array}{c}\text { No. Each } \\
\text { Product to } \\
\text { Achieve } \\
3 \text { 3mol/day in } 8 \\
\text { hrs }\end{array}$ \\
\hline 2500 & Ambient Light & 2500 & 100 & 249 & 10 & 3 & 0.4 \\
\hline 2500 & Grating & 1250 & 50 & 124 & 5 & 7 & 1 \\
\hline 2500 & SunTunnel & 923 & 37 & 92 & 4 & 9 & 1 \\
\hline 2500 & Metal Halide Light & 556 & 22 & 55 & 2 & 15 & 2 \\
\hline 2500 & 3 Prisms & 463 & 19 & 46 & 2 & 18 & 2 \\
\hline 2500 & 1 Prism & 406 & 16 & 40 & 2 & 21 & 3 \\
\hline
\end{tabular}

(a) $3 \mathrm{~mol} / \mathrm{m}^{2} / \mathrm{d}$ is shown to satisfy eelgrass growth needs (Thom and Shreffler 1996)

The number of light products, based on the total distance and proportion of air and water that the light must pass through to reach eelgrass, is shown in Figures 13, 14, and 15. In each figure, total distance light travels is $3 \mathrm{~m}(10 \mathrm{ft}), 4.73 \mathrm{~m}(15.5 \mathrm{ft})$, or $6.5 \mathrm{~m}(21 \mathrm{ft})$. The y-axis then partitions the total distance into a distance light travels through air (given) and through water (difference between total distance and distance through air).

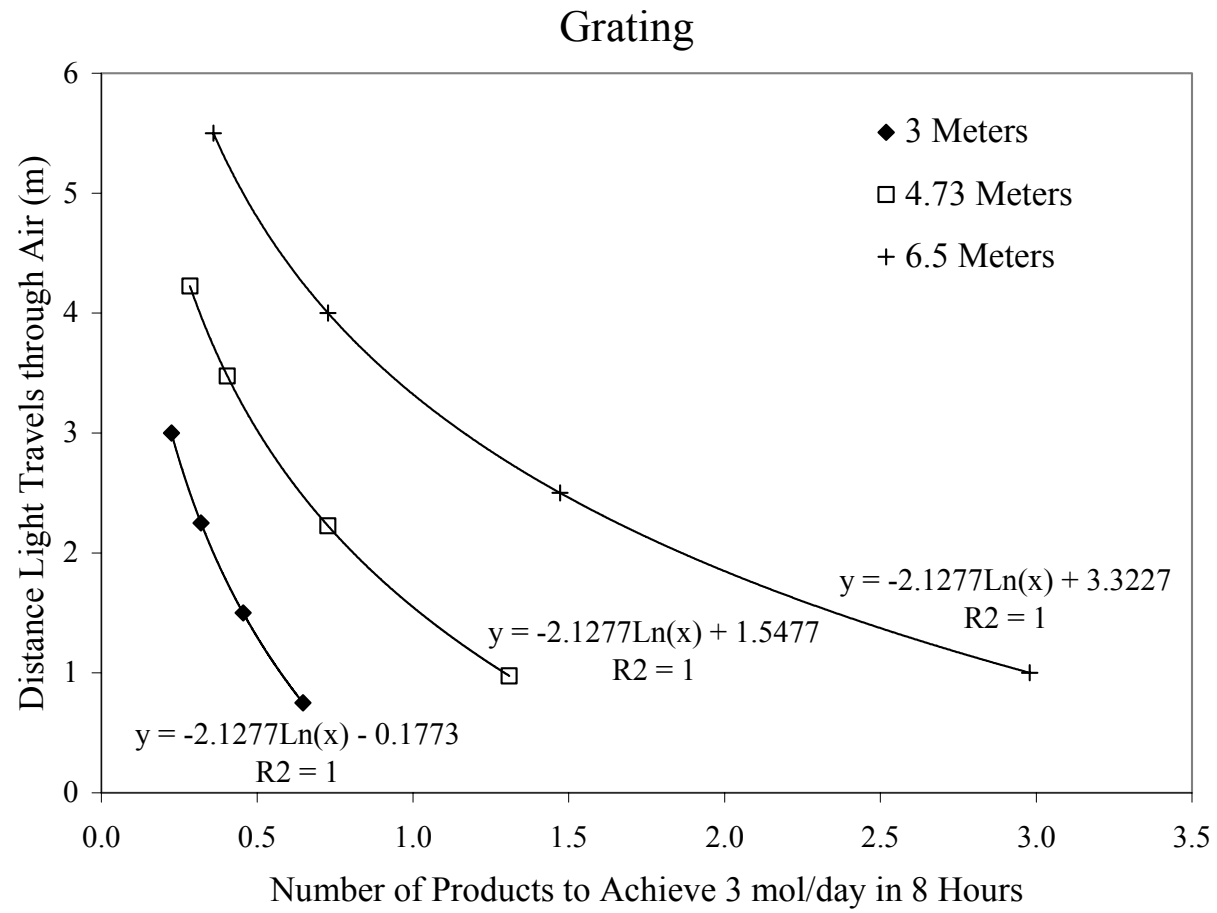

Figure 13. Amount of grating required to achieve $3 \mathrm{~mol} /$ day in 8 hours. In this case, however, multiple gratings are not an option. 


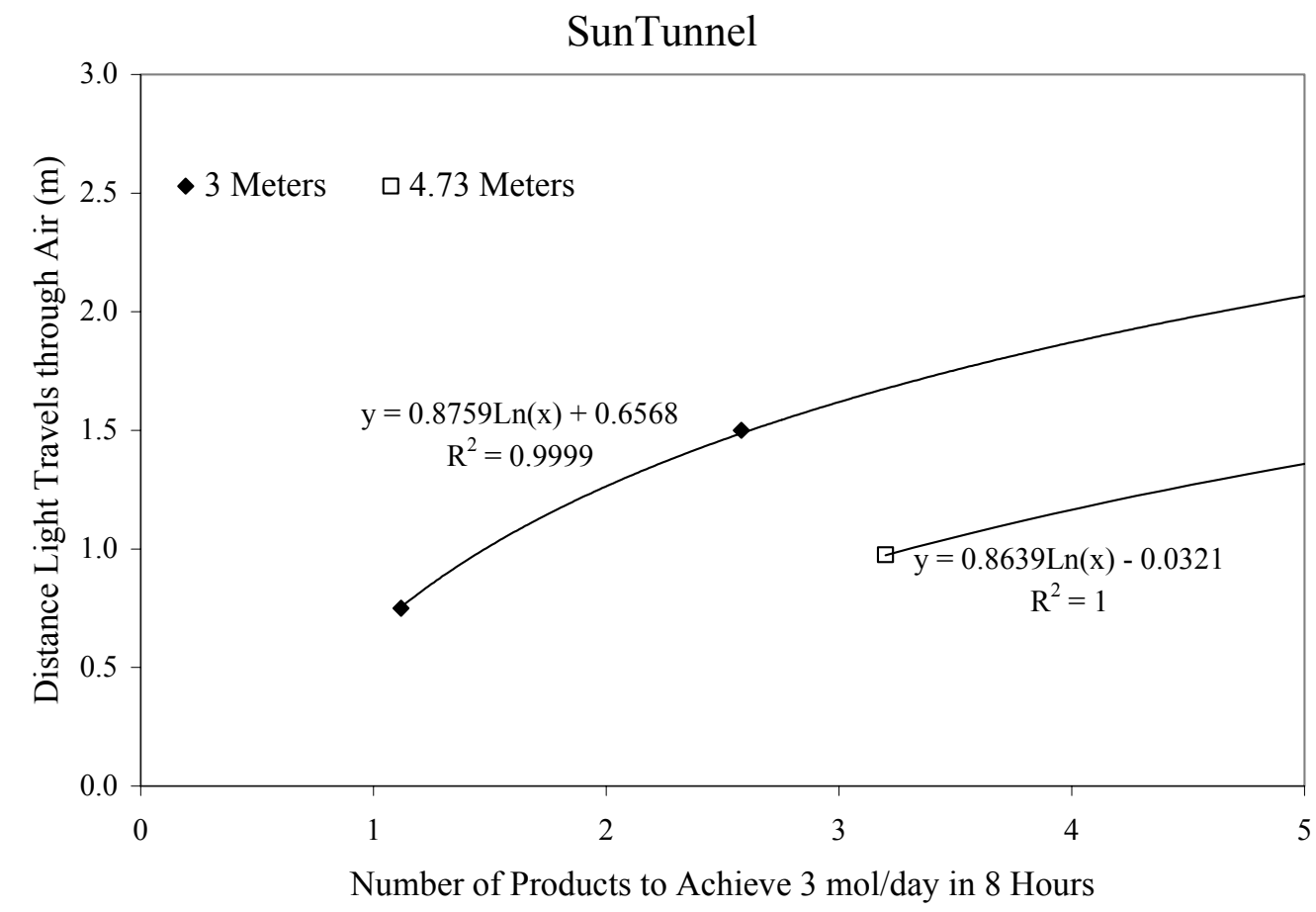

(a)

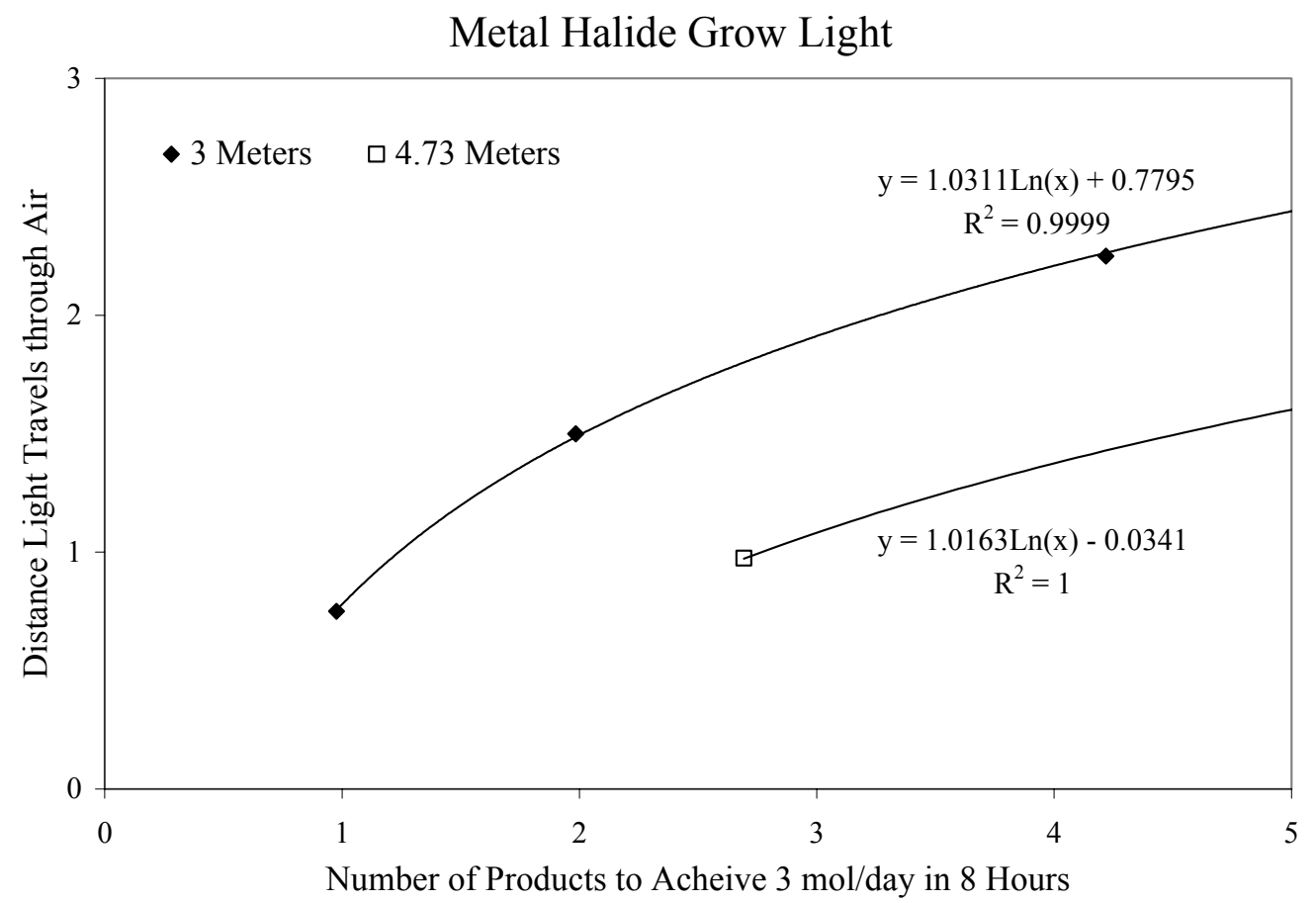

(b)

Figure 14. Number of SunTunnels (a) and metal halide grow lights (b) required to achieve 3 mol/day in 8 hours. 


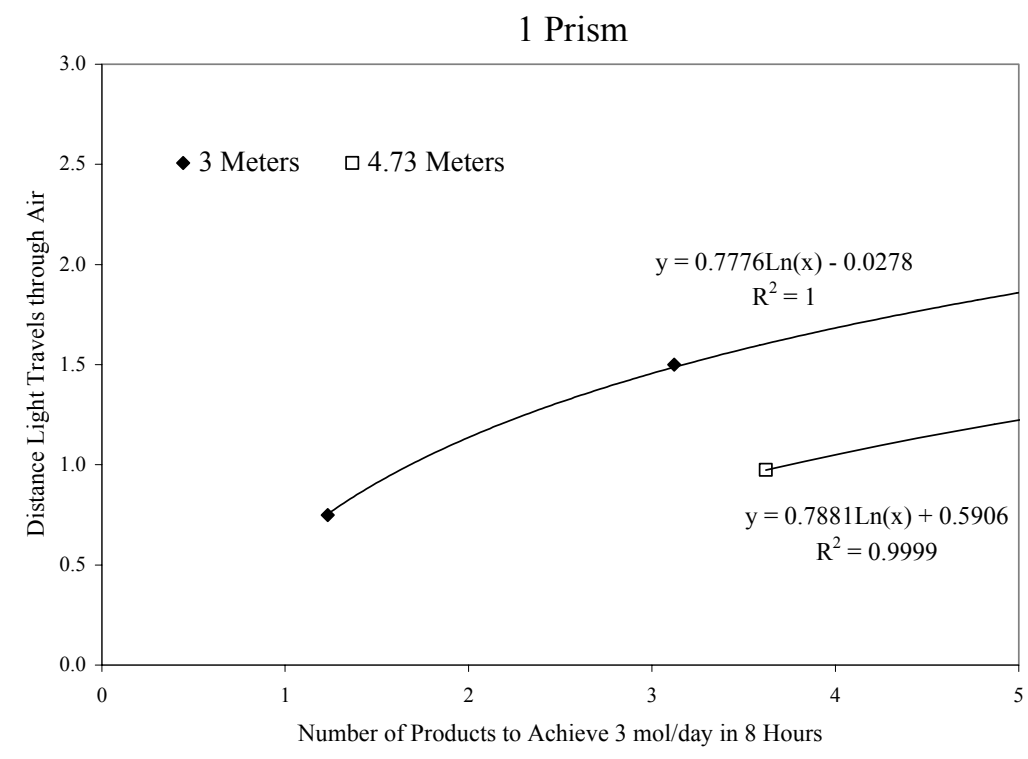

Figure 15. Number of prisms required to achieve $3 \mathrm{~mol} /$ day in 8 hours.

\section{Measurements at the Dock}

Light attenuation measured under the Thomas Oil Dock highlighted the difference between a controlled study and a field study. Immediately underneath the SunTunnel and prism, the in-air PAR was low because of deep shading between the wood stringers supporting the dock (Figure 16). Measured light levels increased with distance from the underside of the dock because the sensor was exposed to more reflected sunlight penetrating under the side of the dock. The period of greatest darkness under the dock, both in air and in the water, was near noon when the sun was at its zenith. Attenuation data associated with the prism was similar to that of the SunTunnel, except that light penetration was not as great under the water surface. This is most likely due to the variability in ambient light levels between the days attenuation data were collected for the SunTunnel and prism.

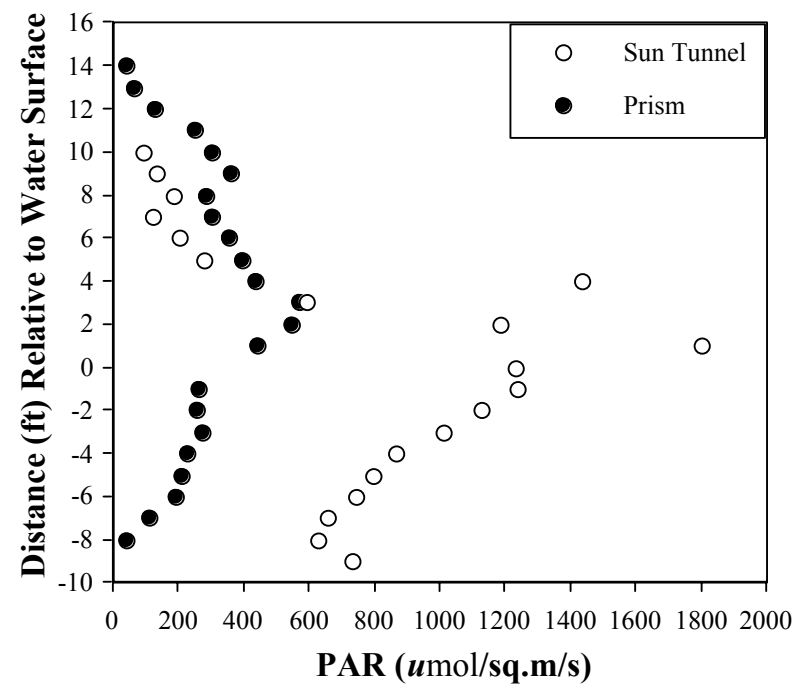

Figure 16. Light Attenuation Curves for Light Products Tested at the Thomas Oil Dock, Port Townsend, Washington. 


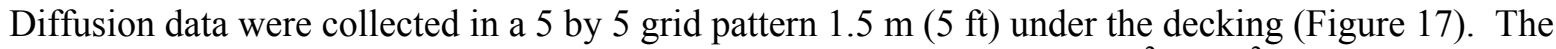
sample stations were approximately $0.5 \mathrm{~m}(1.5 \mathrm{ft})$ apart and covered a $4 \mathrm{~m}^{2}\left(43 \mathrm{ft}^{2}\right)$ area. The light patterns graphed over the course of the day clearly show how sun position influences the amount of light. At midday, the sun was highest in the sky and light levels dropped rapidly under the dock, to nearly $0 \mu \mathrm{mol} / \mathrm{m}^{2} / \mathrm{s}$ less than $102 \mathrm{~cm}$ (40 inches) from the edge of the dock. By $1700 \mathrm{hrs}$, the sun was lower on the horizon and shining nearly perpendicular to the length of the dock, so that light extended much further underneath and light levels exceeded $300 \mu \mathrm{mol} / \mathrm{m}^{2} / \mathrm{s}$.

(a)
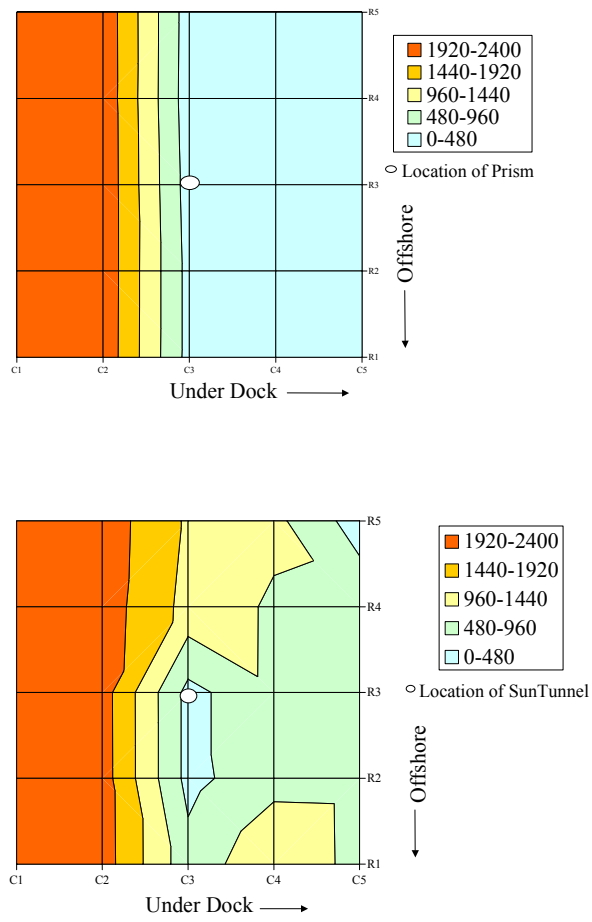

(c)

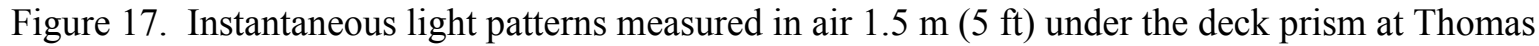
Oil Dock, Port Townsend, Washington at (a) $1300 \mathrm{hrs}$ and (b) $1650 \mathrm{hrs}$. Mean light diffusion patterns for all samplings for the (c) SunTunnel and (d) Deck Prism tested at the Thomas Oil Dock. All measurements are recorded in $\mu \mathrm{mol} / \mathrm{m}^{2} / \mathrm{s}$.

\section{Glass Blocks and Grating at Clinton Ferry Terminal}

Light data along transects under the ferry dock were collected during 2000 and 2001, before and after installation of glass blocks along the pedestrian walkway. It appears that the glass blocks increase the proportion of ambient light under the edge of the terminal (Figure 18). Based on a ratio of incident PAR at the edge of the dock and PAR at the inner edge of the glass blocks, glass blocks allow about 10 percent more light under the edge of the dock. The ratio of ambient light at the south edge of the dock to the innermost edge of the glass blocks was 0.40 without blocks compared to 0.50 with the glass blocks. More monitoring of this site will be conducted in subsequent years to verify the findings. 


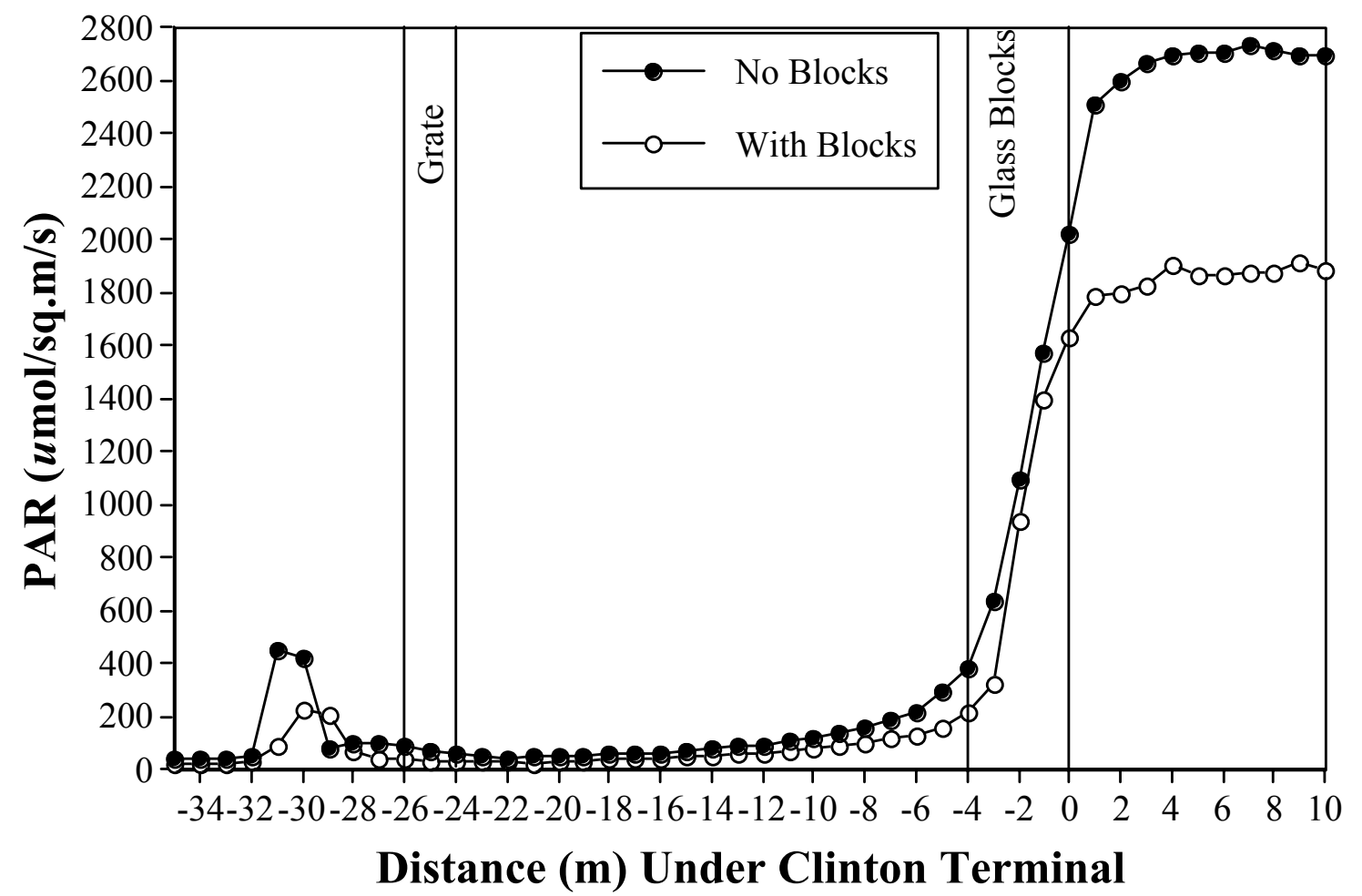

Figure 18. Light transects under the Clinton Ferry Terminal, showing average in-air PAR in 2000 (without glass blocks) and in 2001 (with glass blocks).

In addition to measuring light under the dock, light was measured just above the glass blocks. The pedestrian walkway is bounded on the south side by large clear glass panels, and is roofed overhead by arched panels of frosted glass (Figure 9). At low sun angles, most light enters through the side glass panels, but as the sun rises overhead more light enters through the roof. The sensor was positioned so it measured either light that passed through the glass wall or through the roof. The amount of PAR that passed through the clear glass walls was twice as great as the amount of light that passed through the frosted glass roof panels (Table 3). Only 32 to 64 percent of the ambient light was available over the glass blocks for further propagation of eelgrass underneath the dock.

Table 3. Light measured over the glass blocks along the pedestrian walkway at Clinton Ferry Terminal compared to ambient light levels.

\begin{tabular}{lcc}
\hline & Mean PAR $\left(\mu \mathrm{mol} / \mathrm{m}^{2} / \mathrm{s}\right)$ & Percent \\
\hline Light under Frosted Glass Roof & 697 & 32 \\
Light through South-facing Glass Window & 1413 & 64 \\
Ambient Light & 2195 & 100 \\
\hline
\end{tabular}

Light under the grating was brightest around noon, when the sun was highest overhead. Light was almost entirely blocked at other times of the day, when the sun was at a lower angle in the sky (Figure 18). While not approaching ambient light levels at any time during the day, PAR measurements in air under the portion of the dock with the metal grating averaged 14 percent of ambient, with a maximum of 44.5 percent ambient measured between 1150 and 1202 on May 25, 2001. The grating is installed 
so the long axis of the openings is in a northeast-southwest orientation, where a north-south orientation would be expected to pass the most light by diminishing interference from the vertical walls of the grating. The width of the metal grating was approximately $2 \mathrm{~m}(6.6 \mathrm{ft})$, and the width of the associated zone of enhanced light at the $0 \mathrm{ft}$ MLLW contour was about $3 \mathrm{~m}(9.8 \mathrm{ft})$. Thus, sunlight penetrating the metal grating can provide light to eelgrass over a larger area than the surface area of the grating.

\section{Discussion}

\section{Seagrass Growth}

All of the light technologies tested could provide enough light for eelgrass growth underneath a ferry terminal of similar construction as the Clinton Ferry Terminal if certain requirements are met. For example, all of these products would provide adequate light under conditions where eelgrass is located at its upper depth limit and the dock is within $3 \mathrm{~m} \mathrm{(10} \mathrm{ft)} \mathrm{of} \mathrm{the} \mathrm{eelgrass.} \mathrm{Data} \mathrm{developed} \mathrm{in}$ this study can be used to estimate the number of products that would be required. At Clinton, we estimated that light from the tested products traveled at least $1 \mathrm{~m}(3.4 \mathrm{ft})$ through air and through 2.8 $\mathrm{m}(9.1 \mathrm{ft})$ of water. Increasing or decreasing these distances will change the effectiveness of the lighting systems.

Burdick and Short (1998) examined characteristics of docks that influence shading effects. By charting the dimensions and structural characteristics of docks in two Massachusetts estuaries, reviewing the physical characteristics of the sites (water depth and light penetration) and eelgrass population characteristics (shoot density, canopy height, and growth rate) they were able to create a model for eelgrass bed quality and light availability. In summary, height of the dock above the marine bottom is the primary factor affecting eelgrass bed quality and light availability. Dock orientation was more important than dock width, with north-south oriented docks supporting the most eelgrass.

The minimum light required for persistence of a plant species is often defined by the percentage of surface irradiance that reaches the lower depth limit of the species. Z. marina requires a minimum of 10 to 20 percent of ambient light levels (Duarte 1991, Dennison et al. 1993) or daytime light levels above $300 \mu \mathrm{mol} / \mathrm{m}^{2} / \mathrm{s}$ (Thom and Shreffler 1996) to saturate photosynthesis. Z. marina requires approximately $3.0 \mathrm{~mol} / \mathrm{m}^{2} / \mathrm{d}$ in spring-summer to flourish through the winter (Thom, 1994 unpublished data). However, less light may be able to sustain a net positive carbon balance, and thus allow plants to survive (Zimmerman 1994). These light requirements are relatively high and about twice that required to support macroalgae growth, as summarized in Lobban et al. (1985). Currently, eelgrass beds are present along 35 percent of shorelines in Washington (WA DNR 2001), which also harbor more than 3,000 docks. Ideally, light could be introduced under these overwater structures to create larger, contiguous eelgrass beds that would support juvenile salmonid food resources and refuge.

Shafer (1999) quantified the effects of shading on the seagrass Halodule wrightii. She noted that the seagrass was able to persist under docks where light levels were as low as $16 \%$ of surface irradiance, but that seagrasses were not present under any docks where light levels were less than $14 \%$ surface irradiance. Plants growing in the shaded regions exhibited reduced density and biomass, but increased chlorophyll content and blade length relative to plants growing in unshaded plots.

Additional research into the effectiveness of installing deck prisms in overwater structures as a means to promote seagrass growth is ongoing in Florida. McKinney (2001, pers.com.) and others from the 
St. Johns River Water Management District in Florida are redesigning single-family residential dock structures to minimize impacts to submerged aquatic vegetation, with emphasis on Vallisneria americana. Their goal is to re-direct existing available light under docks to increase underwater illumination (PAR) without increasing dock height, board spacing, or installing expensive grating material. Prisms are placed in three experimental platforms at a density of 1.3 prisms $/ \mathrm{m}^{2}(0.4$ prisms/ $\left.\mathrm{ft}^{2}\right)$. Each conical prism disperses light in a pattern $0.6 \mathrm{~m}(2 \mathrm{ft})$ in diameter. The platforms $(3$ with prisms and 3 without prisms) are $7.3 \mathrm{~m}$ (1) $\times 1.5 \mathrm{~m}(\mathrm{w}) \times 1.5 \mathrm{~m}$ (above mean high water ) ( $24 \mathrm{ft} \times 5 \mathrm{ft}$ x $5 \mathrm{ft}$ ). Three control areas, vegetated areas without platforms, are also monitored for changes in submerged aquatic vegetation (SAV) populations, water quality, and light. Preliminary data indicate that over a 5-month period, there was an average $4 \%$ to $6 \%$ surface irradiance under docks with prisms and an average 3\% to $4 \%$ surface irradiance under docks without prisms. While this is not a great amount of light, the St. Johns River is a freshwater system where submerged aquatic plants have lower light requirements than do seagrasses in marine systems, such as where our studies with lighting technologies were conducted. In general, while seagrasses require approximately $20 \%$ of surface irradiance, some freshwater and estuarine grasses require only 1 to $10 \%$ surface irradiance to survive. Mean SAV percent cover prior to research was similar for the control and tested sites. One year post-construction, the mean SAV percent cover was significantly different between all three sites, with mean SAV decreasing from the control (66.1\% cover) to docks with prisms ( $47.8 \%$ cover) to docks without prisms ( $36.1 \%$ cover). Thus, when used in a much smaller-scale situation than under a ferry dock, the use of prisms in an overwater structure appears to aid SAV growth.

\section{Grating}

An investigation of alternative decking materials, including acrylic, acrylic with matting, lexan, aluminum grating, and fiberglass grating concluded that only fiberglass grating material showed promise for supporting seagrass growth and survival under single-family residential docks (Molnar et al. 1989). Shafer and Robinson (2001) examined the effect of fiberglass grate panels as decking material on Thalassia testudinum seagrass growth and survival in St. Andrew Bay, Florida. They determined that light levels immediately under the grid platforms were between 53 and 61 percent of their unshaded control stations, which was consistent with the manufacturer's rating of 50 percent light transmittance for the material. While the platforms investigated by Shafer and Robinson had dimensions of only $2.4 \mathrm{~m}$ by $3.7 \mathrm{~m} \mathrm{(} 8 \mathrm{ft}$ by $12 \mathrm{ft}$ ) and 1.2 to $1.5 \mathrm{~m}$ ( 4 to $5 \mathrm{ft})$ above mean high water, the decking they investigated is available from several manufacturers and comes in a variety of sizes and thicknesses. The suitability of their use for large ferry docks, however, is questionable because ferry terminal docks support significant loads and these materials may not be suitable for structural integrity and safety reasons. At the levels of shading investigated by Shafer and Robinson, seagrasses were not eliminated, but density and percent cover were reduced compared to adjacent unshaded areas.

Beal and Schmit (1999) tested the effectiveness of two cost-effective alternatives to wood deck planking for increasing irradiance under small dock structures, representative of single-family residential docks. The materials tested were complete fiberglass decking (squares on 3.8-cm (1.5inch) centers and $3.8 \mathrm{~cm}$ (1.5 inch) thick) and half fiberglass decking (the same fiberglass decking, alternated with wood decking). Results to date are inconclusive as to whether half-grating is functionally comparable to whole-grating, though there appear to be only slight differences between the two types (whole-grating allowing slightly more light to penetrate). However, slight differences in PAR under the two treatments could be biologically significant. The authors suggest that grating may be cost-effective based on its longevity and ease of installation. However, they also suggest using the largest openings and minimum thickness possible, to allow maximum light penetration. In general, there is a trade-off between opening size and safety; thickness and strength. 
Fresh et al. (2001) investigated the effects of using light-permeable grating on residential floats in Puget Sound to prevent loss of eelgrass underneath or adjacent to the float. The authors found that even with up to 50 percent of the deck grated, there was still a "net loss" of eelgrass. While no single cause of eelgrass shoot density decline was identified, the orientation of the float and its seasonal removal were important in influencing changes in eelgrass density.

\section{Reflective Material}

Gayaldo et al. (2001) used $2.0 \mathrm{~mm}$ (.08 inch) alumino-metallic Mylar-type film attached to $1.2 \mathrm{~m}$ by $2.4 \mathrm{~m} \mathrm{(4 \textrm {ft } b y ~} 8 \mathrm{ft}$ ) sheets of plywood to reflect sunlight beneath the southern portion of a dock into the submarine environment in Anacortes, Washington. Five panels were installed against the underside of the dock and five panels were attached along the dock pilings (perpendicular to the water surface) and to the overhead panels. The vertical panels were always at least $2.1 \mathrm{~m} \mathrm{(7ft)}$ above mean high water (Gayaldo, pers.comm.). The installation of the reflective panels increased ambient submarine light from $1-3 \%$ to $9-11 \%$ of full sunlight. This appeared to be enough to allow rhizomatous recolonization of $Z$. marina in the region studied. The difference between increases in submarine PAR between parts of the dock with and without the reflective panels was greatest in winter when the sun is at a lower angle, allowing more light to penetrate beneath the dock.

Experiments using foil-covered plywood mounted under a dock parallel to the water surface were also conducted at MSL (Simenstad et al. 1997). Almost two times more light was reflected from the foil as compared to the dark underside of the dock, though the reflected light was diffused by the time it reached the water surface, approximately $6 \mathrm{ft}$ below the foil. Overall, filling the underside of the dock with reflective material parallel to the decking could double the initial reflected light under the dock.

Our observations in the present study suggest that reflected light is a very important source of light under docks. Coupling of technologies that allow light penetration through the dock with products that reflect light may be effective at substantially improving light conditions.

\section{Fish Behavior}

Another reason to provide light under the docks is that active feeding by juvenile salmonids decreases in the dark and ceases completely below 0.0001 foot-candles (approx. $0.0005 \mathrm{umol} / \mathrm{m}^{2} / \mathrm{s}$ ) (Ali 1959). This requisite light level (nearly the intensity of a clear night with a new moon) was achieved in summer beneath four of five Washington State Department of Transportation (WSDOT) ferry docks monitored in a previous study (Simenstad et al. 1999). However, the study could not rule out the possibility that under some conditions (e.g., late winter to spring light, high attenuation) the darker portions of these terminals may not achieve the light level required for maximum feeding. Based on Ali's (1959) findings, our research indicates that installing any of the tested light products would likely maintain light levels under the dock above those required for active feeding by juvenile salmonids.

Similarly, juvenile salmonids tend to prefer to migrate along the edges of dark areas. Ali (1959) studied the retinal response of juvenile salmonids (coho, chum, pinks, and sockeye) in early life stages ranging from embryos to smolts. Essentially, Ali found that the time required for fish to adapt to the dark increased with age, and generally required 35 to 40 minutes in salmon fry each time their eyes made the full adjustment from bright light to darkness. Entering water shaded by a dock can evidently cause a state of partial blindness in fish, which they may actively try to avoid. The existence of multiple overwater structures may compound the problems and lead to delayed 
migration. The consequences of delayed migration are unknown, but are assumed to be detrimental (Simenstad et al. 1999). No study of fish movement through shade barriers was identified during this study, so it is unknown what threshold of light-dark contrast juvenile salmon will swim through. However, light levels needed to allow fish to feed and to form schools are reported to be low $(\sim 1-2$ $\mu \mathrm{mol} / \mathrm{m}^{2} / \mathrm{s}$ ), and much less than those required for photosynthesis (Ali 1959). To minimize this potential barrier to salmon movement, however, it would be beneficial to decrease the dark edge effect if possible. The physical design (e.g., dock height and width, dock orientation, construction design materials, piling type and number, etc.) will influence whether the shadow cast on the nearshore covers a sufficient area and scope of darkness to constitute a barrier. Placement of glass blocks or grating material at the edge of a dock may help reduce the contrast between light and dark.

\section{Cost/Maintenance}

The cost and maintenance of the various light-enhancing products must be considered in addition to the effectiveness of the product at providing light below the overwater structure (Table 4). In this study, the SunTunnel was most expensive (\$429), followed by the deck prisms (\$116 each) and the metal halide light (approx \$50). The deck prisms, however, would likely be the simplest to maintain, followed by the SunTunnel. Although the metal halide lights have a life expectancy of at least 10,000 hrs (nearly 2.3 years operating $12 \mathrm{hrs} / \mathrm{d}$ ), the lights would have to be protected from water damage and power would have to be supplied. Solar power is an option, but mean light levels in western Washington State make this less feasible than in other parts of the country. Maintenance for a SunTunnel or deck prisms would involve periodic cleaning of the surface exposed to the elements.

Reflective material, such as Mylar, comes in thicknesses up to $5 \mathrm{~mm}$ (0.2 inches). As long as the reflective material is attached firmly so it will not be damaged by wind or waves, it should last 2 years or longer before the reflective coating dulls. Interim cleaning may help to maintain reflectivity (Gayaldo, pers. comm.)

Although generally more expensive than alternate decking materials (e.g., asphalt or wood), grating is considered easy to install and requires little in the way of maintenance. Grating materials made today are strong and durable and often include skid-proof surfaces. However, while skid-proof surfaces are important in pedestrian areas, the structural issues related to cars driving over grated surfaces and the potential for leaking petroleum products to pass through grating usually rules out the use of this material at WSF terminals. 
Table 4. Costs and benefits associated with lighting products.

\begin{tabular}{|c|c|c|}
\hline Light Product & Costs & Benefits \\
\hline Deck Prism & Less efficient at passing light & $\begin{array}{l}\text { Inexpensive, may be able to be placed in } \\
\text { deck surface, aesthetically pleasing }\end{array}$ \\
\hline Glass Blocks & Potential safety/strength issues & $\begin{array}{l}\text { Pass a good amount of light, } \\
\text { aesthetically pleasing }\end{array}$ \\
\hline Grating & $\begin{array}{l}\text { Expensive, potential safety/strength } \\
\text { issues }\end{array}$ & $\begin{array}{l}\text { Passes lots of light, little maintenance } \\
\text { required }\end{array}$ \\
\hline Greenhouse Light & $\begin{array}{l}\text { Maintenance, cost of electricity (unless } \\
\text { solar-powered), electrical safety }\end{array}$ & $\begin{array}{l}\text { Constant bright light source, even when } \\
\text { it's dark outside }\end{array}$ \\
\hline Reflective Material & $\begin{array}{l}\text { Temporary (Mylar lasts } 2-5 \text { yrs; paint } \\
\text { probably longer) }\end{array}$ & $\begin{array}{l}\text { Provides a small amount of } \\
\text { supplemental lighting }\end{array}$ \\
\hline SunTunnel & $\begin{array}{l}\text { Cost/unit, locating on dock may be } \\
\text { problematic }\end{array}$ & $\begin{array}{l}\text { Tubes extend easily through dock } \\
\text { thickness, relatively bright light can be } \\
\text { directed at an angle }\end{array}$ \\
\hline
\end{tabular}

\section{Recommendations}

The light passing through air, underneath the products evaluated, and penetrating water to reach the substrate under a dock is affected by a number of factors. The turbidity of the water, the amount of ambient light, the type of lighting product, and the amount of air and water light must pass through are all limiting factors. However, the results of this research do enable engineers to predict the amount of light that could reach plants or fish under a dock after passing through one of the light products investigated. Variables are the light attenuation coefficient, $\mathrm{Kd}$, of the region being investigated, the mean sea level, the height of the dock and slope of the ground underneath it, and the type of lighting product.

Because light requirements to sustain eelgrass growth are relatively high, efforts to do so by installing lighting products, such as those evaluated in this study, should be concentrated on regions of the dock where the underlying substrate is suitable for eelgrass growth. Also, products should be installed over areas where the distance between the underside of the deck and the substrate will allow adequate light penetration for the desired outcome (i.e., eelgrass growth, macroalgae growth, fish movement). In general, this will likely result in a nearshore lighting corridor, parallel to shore. The effective width of the corridor would be inversely related to the steepness of the slope offshore.

Grating materials would be most effective at providing enough light for eelgrass growth, but the issues related to its structural integrity and safety may limit its use to small regions where traffic would not cross it and where surface runoff would not be able to pass through it to the water below. It is most effective, relative to the other products, when the deck surface is high above the mean water surface ( $>3 \mathrm{~m}$ or $10 \mathrm{ft}$ ). SunTunnels are the second-most effective option. Again, there are likely limited positions on the deck where a SunTunnel could be installed. Likely positions include along the outer edge of the deck where cars do not travel, such as next to the supports of the pedestrian walkway at Clinton. Metal halide lights would be able to provide enough light for eelgrass growth in many circumstances, but providing electricity and maintenance while keeping the lights out of the water may make them less desirable than some of the other options. Prisms, en mass, may be structurally sound and able to provide light for eelgrass growth under some deck configurations. In regions where the water is usually close to the underside of the deck, prisms would be a good option. Where the deck stands high above the substrate $(>3 \mathrm{~m}$ or $10 \mathrm{ft})$, prisms become less viable. 
That said, each of the evaluated products would be useful in providing light for purposes other than sustaining eelgrass under the dock. Kelp and macroalgae provide habitat for other fish and invertebrate species and require lower light levels than eelgrass. Where eelgrass requires 300 $\mu \mathrm{mol} / \mathrm{m}^{2} / \mathrm{s}$, upper and mid-sublittoral macroalgae species generally require only $150-250 \mu \mathrm{mol} / \mathrm{m}^{2} / \mathrm{s}$ for saturation, and kelp species require even less (Lüning 1981).

According to Ali (1959), light levels required for fish feeding are even lower, around $1-2 \mu \mathrm{mol} / \mathrm{m}^{2} / \mathrm{s}$, and providing even a small amount of light in a regular pattern under a dock may encourage fish to swim underneath. A large region where deck prisms are installed could provide enough light for fish to comfortably navigate under the dock during the day, so long as they will swim thorugh any sharp light gradient along the edge of the dock. Intuitively, minimizing the light contrast along the dock edge is best way to pass fish under the structure. By allowing light levels to decrease gradually along the edge, the eyes of the fish should be able to adjust more rapidly to low-light conditions than when the contrast is sharp. Grating or glass blocks along the edge, that are not shaded by any overhead structure may smooth the transition.

The following suggestions are made with WSF docks in mind. Smaller overwater structures could benefit from the use of light-enhancing products in additional ways.

- To support or enhance eelgrass growth, a band of grating or SunTunnels should be placed in nearshore areas where suitable substrate exists under the dock along the intertidal/subtidal corridor where eelgrass has the greatest chance for survival. Lighting would be enhanced if reflective material were also placed on the underside of the dock. If the total distance from the underside of the dock to the substrate is less than $3 \mathrm{~m}(10 \mathrm{ft})$, a concentration of deck prisms would also be a viable option.

- In regions where the dock is $>3 \mathrm{~m}$ (10 ft) above the substrate, tighter clustering of light products would be necessary to support eelgrass growth. If it is not appropriate to support eelgrass growth in that area, then fewer products would be necessary to enhance juvenile salmonid penetration under the dock for feeding or migration purposes.

- Reflective panels, mounted parallel to the water surface and/or mounted perpendicularly to the water surface and oriented to reflect southern sunlight, should supplement any other lighting technique.

- Grating (if it is not square) should be installed so that the long axis runs north-to-south. Thinner grating with wider spacing allows more light to penetrate under the structure.

- Natural sunlight should encounter the lighting product as much as possible. The more layers light must pass through before reaching the light product, the more dissipated the light becomes before it reaches the water (e.g., the frosted glass panels spanning the top of the pedestrian walkway reduce sunlight reaching the glass blocks at the Clinton Ferry Terminal).

- Efforts made to dissipate the dark shadows and reduce the light-dark contrast along the edges of the dock may encourage juvenile salmon to swim under the dock. Grating material or glass blocks could serve this purpose.

- Installation of light-enhancing products may be especially important for enhancing light levels during normally low light periods (i.e., early morning and late evening). 


\section{Acknowledgements}

We sincerely acknowledge the cooperation, assistance, and dedication of the following agencies and people:

- Washington State Department of Transportation (WSDOT): for its support of this research; in particular, we gratefully acknowledge Jim Schafer, Kojo Fordjour, and Jim Toohey for their continued interest in the project.

- Dave Robison, Northwest Maritime Center, for providing unlimited use of the Thomas Oil Dock for our studies and for making available the kayak used to measure light under the dock.

- Deborah Shafer, Waterways Experiment Station: for providing information on grating technologies.

- Alicia McKinney, St. Johns River Water Management District: for taking time to discuss the preliminary results of her work with prisms in overwater structures.

- Perry Gayaldo, National Marine Fisheries Service: for his open discussion on the merits of reflective materials.

- Pat Fallon, Battelle Marine Sciences Laboratory: for constructing the "Obelisk of Darkness".

- The reviewers: those not already mentioned include Lennie Rae Cook and Tracey McKenzie of PI Engineering, Si Simenstad at the University of Washington, and Blythe Barbo at the Battelle Marine Sciences Laboratory. 


\section{References}

Ali, M.A. 1959. The ocular structure, retinomotor and photo-behavioral responses of juvenile Pacific salmon. Canadian Journal of Zoology. 37: 965-996.

Burdick, D.M. and F.T. Short. 1998. The effects of boat docks on eelgrass beds in coastal waters of Massachusetts. Environmental Management. Vol. 00, No. 00, pp. 1-11.

Dennison, W.C., R.J. Orth, K.A. Moore, J.C. Stevenson, V. Carter, S. Kollar, P.W. Bergstrom, and R.A. Batiuk. 1993. Assessing water quality with submersed aquatic vegetation. BioScience 43:8694.

Duarte, C.M. 1991. Seagrass depth limits. Aquatic Botany. 40: 363-377.

Fresh, K.L., S. Wyllie-Echeverria, and T. Wyllie-Echeverria. 2001. Mitigating impacts of overwater floats on eelgrass Zostera marina in Puget Sound, Washington. Presented at Puget Sound Research 2001, February 12-14, 2001, Bellevue, Washington.

Gayaldo, P., S. Wyllie-Echeverria, and K. Ewing. 2001. Transplantation and alteration of submarine environment for restoration of Zostera marina (eelgrass); a case study at Curtis Wharf (Port of Anacortes), Washington. Presented at Puget Sound Research 2001, February 12-14, 2001, Bellevue, Washington.

Kirk, J.T.O. 1994. Light and photosynthesis in aquatic ecosystems, $2^{\text {nd }}$ ed. Cambridge University Press, Cambridge, England.

Lobban, C.S., P.J. Harrison, and M.J. Duncan. 1985. The physiological ecology of seaweeds. Cambridge University Press. New York.

Lüning, K. 1981. Light in Lobban, CS and MJ Wynne (eds.). The Biology of Seaweeds. Pages 326-355. Blackwell Scientific Publications, Oxford, England.

Molnar, G. S. Markley, and K. Mayo. 1989. Avoiding and minimizing damage to Biscayne Bay seagrass communities from the construction of single family residential docks. DERM Technical Report 89-7, Metro Dade Department of Environmental Resources Management, Miami, Florida.

Penttila, D. and D. Doty. 1990 (DRAFT). Results of 1989 eelgrass shading studies in Puget Sound. Washington Department of Fisheries, Marine Fish Habitat Investigations Division.

Personal Observation. 2001. John Southard and Sue Blanton, Research Scientists, Battelle Marine Sciences Laboratory, Sequim, Washington. Observation of juvenile salmonids at Clinton Ferry Terminal.

Shafer, D.J. 1999. The effects of dock shading on the seagrass Halodule wrightii in Perdido Bay, Alabama. Estuaries 22(4): 936-943.

Shafer, D.J. and J. Robinson. 2001. An evaluation of the use of grid platforms to minimize shading impacts to seagrasses. WRAP Technical Notes Collection (ERDC TN-WRAP-01-02), U.S. Army Engineer Research and Development Center, Vicksburg, MS. www.wes.army.mil/el/wrap 
Simenstad, C.A., B.J. Nightingale, R.M. Thom, and D.K. Shreffler. 1999. Impacts of ferry terminals on juvenile salmon migrating along Puget Sound shorelines. Phase I: Synthesis of state of knowledge. Report No. WA-RD 472.1. Washington State Transportation Center (TRAC), Seattle, Washington.

Simenstad, C.A., R.M. Thom, and A.M. Olson. 1997. Mitigation between regional transportation needs and preservation of eelgrass beds (Volume I). WA-RD 421.1, Washington State Department of Transportation, Olympia, Washington.

Thom, R.M. and D.K. Shreffler. 1996. Eelgrass meadows near ferry terminals in Puget Sound. Characterization of assemblages and mitigation impacts. Battelle Marine Sciences Laboratory, Sequim, Washington.

WA DNR (Washington Department of Natural Resources). 2001. Washington State shorezone inventory. Nearshore Habitat Program, WA DNR, Olympia, Washington.

Zimmerman, R.C. and A.R.S. Cabello-Pasini. 1994. Modeling daily production of aquatic macrophytes from irradiance measurements: a comparative analysis. Marine Ecology Progress Series 114:185-196. 